\title{
Human Development as a Core Objective of Global Intellectual Property
}

J. Janewa OseiTutu

Florida International University College of Law, joseitut@fiu.edu

Follow this and additional works at: https://ecollections.law.fiu.edu/faculty_publications

Part of the Human Rights Law Commons, and the Intellectual Property Law Commons

\section{Recommended Citation}

J. Janewa OseiTutu, Human Development as a Core Objective of Global Intellectual Property, 105 Ky L.J. 1 (2016).

Available at: https://ecollections.law.fiu.edu/faculty_publications/278 


\title{
Kentucky Law Journal
}

VOLUME Io5

$2016-2017$

NUMBER I

\section{ARticles}

\section{Human Development as a Core Objective of Global Intellectual Property}

\author{
J. Janewa OseiTutu
}

\begin{abstract}
Global intellectual property obligations shape domestic laws and policies. More than twenty years since the first multilateral trade-based intellectual property agreement, critics contend that global intellectual property law prioritizes intellectual property rights over other interests, and profits over people. Faced with international intellectual-property obligations, nations have been forced to justify laws and policies designed to promote human development in areas such as health and education as exceptions to intellectual property protection. This is the result of legal interpretations that treat the objectives of intellectual property protection and human development as inconsistent with one another. Drawing on the objectives of trade law and intellectual property law, this Article argues that human development is a central objective of trade-based intellectual property law and should be duly recognized as such. It is therefore unnecessary to protect human development as an "exception" to a norm of protection.
\end{abstract}

\section{TABLE OF CONTENTS}

${ }^{\mathrm{I}}$ J.D., L.L.M., Associate Professor of Law, Florida International University College of Law ("FIU"). I am grateful to the attendees at University of Ottawa Open Air Speaker Series, and the participants of the 2015 Intellectual Property Scholars Conference at DePaul, the 2016 Junior Intellectual Property Scholars Association Workshop at FIU, the FIU 10-10-10 Workshop, and the Indiana Law at Indianapolis Junior Faculty Exchange workshop for helpful comments and discussions. Thanks to Tawia B. Ansah, Margaret Chon, Brian L. Frye, Xuan-Thao Nguyen, Pranesh Prakash, Chidi Oguamanam, Lea Shaver, and Hannibal Travis for their helpful conversations on this project or comments on prior versions of this draft. I am grateful to Dean R. Alexander Acosta for the research support, and I appreciated the able research assistance provided by Dara Jeffries, Ashley Mapp, and Rosangel Rodriguez. I would like to thank R. Nicholas Rabold, Cody S. Barnett, and the other editors of the KENTUCKY LAW JOURNAL for their excellent editorial work. All errors and omissions are mine. 


\section{INTRODUCTION}

Intellectual property laws can play a critical role in promoting or hindering human progress. ${ }^{1}$ But these laws, which regulate ownership in intangible goods, can also lead to moral and ethical dilemmas relevant to human development. ${ }^{2}$ For instance, should a patent owner of self-replicating, genetically-modified seeds be able to control the use of the seeds after they have been harvested, or does this extend the patent right too far? ${ }^{3}$ Should life-saving medicines be made available to those in need, even if they cannot afford them $?^{4}$ Should human genes be owned $?^{5}$ In the interest of promoting public health, should countries be able to limit the ability of companies to use their trademarks to advertise harmful products? Global harmonization of intellectual property laws means that states are restricted in their capacity to make these determinations independently.

When the World Trade Organization ("WTO") Agreement on Trade-Related Aspects of Intellectual Property Rights (“TRIPS Agreement") ${ }^{6}$ came into force over

${ }^{1}$ See Madhavi Sunder, From GoOds TO A GoOd LifE: InTEllectual Property AND GLOBAL JUSTICE 1-22 (2012); Joseph E. Stiglitz, Economic Foundations of Intellectual Property Rights, 57 DukE L.J. 1693, 1696 (2008); Madhavi Sunder, IP', 59 STAN. L. REV. 257, 314 (2006).

${ }^{2}$ See, e.g., Ass'n for Molecular Pathology v. Myriad Genetics, Inc., 133 S. Ct. 2107 (2013).

${ }^{3}$ See Bowman v. Monsanto Co., 133 S. Ct. 1761 (2013); Monsanto Can. Inc. v. Schmeiser, [2004] S.C.R. 902 (Can.); Shubha Ghosh, George Young Bascom Professor of Bus. Law, Univ. of Wis. Law Sch., Speech at UIA Congress: Innovation, Health and the Right to Know: The Law of Food, Fiber and Toxins 5 (Nov. $\quad 1, \quad 2014$ ) (outline available at http://www.uiaflorence2014.com/public/pdf/035_SALA_5_035_GHOSH_SHUBHA_Innovation_H ealth_and_the_Right_to_Know_EN.pdf\#zoom=75) ("The creation of a technology based exemption to the patent exhaustion doctrine is inconsistent with Congress' technology neutral view of patent law, dating back at least to the enactment of the 1952 Patent Act. Such a technology neutral view of patent law is mandated by and consistent with Article 27(1) of the TRIPS Agreement which imposes on signatories the obligation that 'patents shall be available and patent rights be enjoyable without discrimination as to...the field of technology.' The Federal Circuit's exception for self- replicating technologies creates such discrimination based on field of technology.").

${ }^{4}$ See World Trade Organization, Ministerial Declaration of 14 November 2001, WTO Doc. WT/MIN(01)/DEC/1, 41 I.L.M. 746, 748-49 (2002) [hereinafter Doha Declaration].

${ }^{5}$ See World Health Organization [WHO], Genetics, Genomics and the Patenting of DNA: Review of Potential Implications for Health in Developing Countries, 9 Human GeneTICs Programme: CHRONIC Diseases AND HEALTH PROMOTION (2005), http://www.who.int/genomics/FullReport.pdf.

${ }^{6}$ Agreement on Trade-Related Aspects of Intellectual Property Rights, Apr. 15, 1994, Marrakesh Agreement Establishing the World Trade Organization, Annex 1C, ThE LEgAL TeXTs: THE ResulTs of THE URUGUAY ROUND OF Multilateral Trade NegOtiations 320 (1999), 1869 U.N.T.S. 299, 33 I.L.M. 1197 (1994) [hereinafter TRIPS Agreement]. The TRIPS Agreement took effect on January 1, 1995. Overview: The TRIPS Agreement, WORLD TRADE ORG., https://www.wto.org/english/tratop_e/trips_e/intel2_e.htm (last visited Oct. 21, 2016) ("The TRIPS Agreement, which came into effect on 1 January 1995, is to date the most comprehensive multilateral agreement on intellectual property."). 
Io5

twenty years ago, it was the first multilateral agreement to incorporate intellectual property into international trade. ${ }^{7}$ At that time, merging intellectual property with international trade was controversial. "Trade-related" or "trade-based" intellectual property obligations, however, are now a firmly established trend. This means that international trade agreements are shaping domestic intellectual property law.

With a view to improving public health, Australia enacted legislation ("Plain Packaging Legislation") to severely limit the way cigarette companies can market their products. ${ }^{8}$ The Australian law was designed to discourage the public from smoking by requiring cigarette packaging to include photographs and messages about the negative health effects of cigarette smoking. ${ }^{9}$ For instance, some of the packaging states, "smoking causes mouth and throat cancer," and includes a graphic photograph of a mouth and teeth that appear to be ill and in some state of decay. ${ }^{10}$ The photographs and the health warnings must cover the majority of the cigarette packaging. ${ }^{11}$ Naturally, the tobacco companies were unhappy. ${ }^{12}$ The major cigarette companies used investor-state arbitration to challenge the Australian government because the law limited their ability to use their trademarks. ${ }^{13}$

When the cigarette companies were unsuccessful in challenging Australia's laws domestically, they took their fight to international tribunals. The Australian Plain Packaging Legislation has been challenged as a violation of Australia's intellectual property obligations under the WTO agreements. The WTO is the primary global, multilateral institution that regulates trade between most of the world's nations. ${ }^{14} \mathrm{It}$ has a dispute settlement agreement that allows adjudicative panels to hear disputes. ${ }^{15}$

${ }^{7}$ North American Free Trade Agreement, Can.-Mex.-U.S., Dec. 17, 1992, 32 I.L.M. 289 (1993), which predated TRIPS, also had a chapter on intellectual property rights. However, the only countries involved in the NAFTA were Canada, the United States, and Mexico.

8 Tobacco Plain Packaging Act 2011 (Cth) (Austl.); Tobacco Plain Packaging Regulations 2011 (Cth) (Austl.).

9 See, e.g., Mark Davison \& Patrick Emerton, Rights, Privileges, Legitimate Interests, and Justifiability: Article 20 of TRIPS and Plain Packaging of Tobacco, 29 AM. U. INT'L L. REV. 505, 50809 (2014).

${ }^{10}$ See, e.g., Competition and Consumer (Tobacco) Information Standard 2011 (Cth) part $4 \mathrm{~s} 2$ subdivs 1-2 (Austl.).

${ }^{11} I d$.

12 Plain Packaging; BRIT. AM. TOBACCO, http://www.bat.com/plainpackaging (last visited Oct. 19, 2016) (discussing its opposition to plain packaging laws).

${ }_{13}$ Aftinet Media Release, Australian High Court Rules Against Big Tobacco on Plain Packaging, AFTINET, http://aftinet.org.au/cms/node/519 (last visited Oct. 19, 2016); Tobacco Plain PackagingInvestor-State Arbitration, AUSTL. GOV'T, ATT'Y GENS. DEP’T, https://www.ag.gov.au/tobaccoplainpackaging (last visited Oct. 19, 2016).

${ }^{14}$ The World Trade Organization was established in 1994. See General Agreement on Tariffs and Trade 1994, Apr. 15, 1994, Marrakesh Agreement Establishing the World Trade Organization, Annex 1A, The Legal Texts: The Results of the Uruguay Round of Multilateral Trade NEGOTIATIONS 17 (1999), 1867 U.N.T.S. 187, 33 I.L.M. 1154 (1994) [hereinafter GATT 1994].

${ }^{15} \mathrm{Id}$. at 1163. 
A panel has been established to hear the Australia case. ${ }^{16}$ Should the dispute proceed, a dispute settlement panel could decide that Australia's law violates its intellectual property obligations under the WTO agreements and recommend that Australia change its laws to bring them into compliance with its WTO obligations.

The WTO challenge to Australia's Plain Packaging Legislation is indicative of the way international agreements can shape national intellectual property policy. However, as this case illustrates, a successful challenge would also affect Australia's public health policy. Australia's efforts to discourage cigarette smoking are based on sound health policy and are in line with global health goals. For example, the World Health Organization has a "Tobacco Free Initiative." ${ }^{17}$ This initiative was established in 1998 to raise awareness about the negative health effects of tobacco. ${ }^{18}$ The question that the tobacco industry challenge raises is whether Australia's health policy interferes with intellectual property rights.

When international trade panels have had the opportunity to interpret tradebased intellectual property rules, they have interpreted these rules in a manner that characterizes societal goals, like promoting public health, as inconsistent with the intellectual property obligations under the WTO. ${ }^{19}$ However, this is a false dichotomy.

Under the current framework, laws designed to promote human health, such as the Australian Plain Packaging Legislation, are accommodated as exceptions to intellectual property protection. ${ }^{20}$ When sovereign nations develop policies that prioritize certain human development goals, such as access to medicines, these nations are portrayed as free-riders. ${ }^{21}$ This requires nations to defend policies designed to prioritize human development objectives, such as health and education,

${ }^{16}$ Under the WTO Agreements, the tobacco companies cannot challenge Australia directly, but an interested nation can do so on their behalf. Id. See Australia-Certain Measures Concerning Trademarks and Other Plain Packaging Requirements Applicable to Tobacco Products and Packaging, WTO Doc. WT/DS435/1 (Apr. 4, 2012) ("On 10 October 2014, the Chair of the panel informed the DSB that the panel expected to issue its final report to the parties not before the first half of 2016, in accordance with the timetable adopted by the panel on 17 June 2014 on the basis of a draft timetable proposed by the parties. On 29 June 2016, the Chairman of the panel informed the DSB that due to the complexity of the dispute, the panel expected to issue its final report to the parties not before the end of 2016.").

17 Tobacco Free Initiative, WORLD HEALTH ORG., http://www.who.int/tobacco/about/en (last visited Oct. 27, 2016). The World Health Organization also has a Framework Convention on Tobacco Control with 168 signatories. WHO Framework Convention on Tobacco Control, WORLD HEALTH ORG., http://www.who.int/fctc/text_download/en/ (last visited Oct. 27, 2016).

${ }_{18}$ Tobacco Free Initiative, supra note 17.

${ }^{19}$ See, e.g., Panel Report, Canada-Patent Protection of Pharmaceutical Products: Complaint by the European Communities and Their Member States, WTO Doc. WT/DS114/R (adopted Mar. 17, 2000) [hereinafter Canada Patent Pharmaceuticals].

${ }^{20}$ See id.

${ }^{21}$ J. H. Reichman, From Free Riders to Fair Followers: Global Competition Under the TRIPS Agreement, 29 N.Y.U. J. INT'L L. \& POL. 11, 14 (1997). 
Io5

as justified, despite the obligation to protect intellectual property rights. ${ }^{22}$ As a result, national policies that curtail intellectual property interests are defended based on exceptions and "flexibilities" in the WTO agreements, rather than justified as consistent with the primary objectives of a trade-based intellectual property regime.

This Article contends that promoting human progress and innovation should be recognized as an objective of trade-based intellectual property law and the international obligations interpreted accordingly. While this is not the dominant narrative in intellectual property, this argument is not without support. ${ }^{23}$ It is grounded in utilitarian ${ }^{24}$ intellectual property theory and the language of the WTO Agreements. ${ }^{25}$ While human development can mean different things, the definition used here is the one used by the United Nations, which is multi-faceted. ${ }^{26}$ It includes progress in terms of health, education, and economic wealth. ${ }^{27}$ These objectives are aligned with the patent and copyright goals of promoting innovation and progress. These are complementary, not competing objectives.

The central claim of this Article is that promoting human development and progress is an objective of intellectual property law as well as trade law. Moreover, it is an objective of trade-related intellectual property because intellectual property rules that are subsumed within a trade regime are subject to the objectives of the trade regime as well as the objectives of intellectual property law.

Intellectual property laws are relevant to global human development for a number of reasons. First, intellectual property obligations have been incorporated into the WTO agreements, and compliance with intellectual property standards created through the WTO Agreements is mandatory for all WTO member states. ${ }^{28}$ This means that the intellectual property laws and policies of most of the world's nations are shaped, in part, by the WTO Agreements and other agreements, such as the

\footnotetext{
${ }^{22}$ See Request for Consultations by Dominican Republic, Australia-Certain Measures Concerning Trademarks and Other Plain Packaging Requirements Applicable to Tobacco Products and Packaging, WTO Doc. WT/DS441/1 (July 18, 2012); Request for Consultations by the United States, CanadaTerm of Patent Protection, WTO Doc. WT/DS170/1 (May 10, 1999).

${ }^{23}$ While this Article will use the term "intellectual property," the primary forms of intellectual property that are the subject of the analysis contained herein are patent and copyright laws.

${ }^{24}$ I distinguish utilitarianism from wealth maximization because they are not interchangeable, although I acknowledge that maximizing wealth could be used as a measure.

${ }^{25}$ TRIPS Agreement, supra note 6, at pmbl.

${ }_{26}$ See Human Development Index, U.N. Dev. Programme, http://hdr.undp.org/en/content/human-development-index-hdi (last visited Oct. 19, 2016).

${ }_{27}$ The United Nations Development Programme defines human development and the human development approach as "expanding the richness of human life, rather than simply the richness of the economy in which human beings live. It is an approach that is focused on people and their opportunities and choices." What is Human Development?, U.N. DEV. PROGRAMME, http://hdr.undp.org/en/humandev (last visited Oct. 19, 2016). Amartya Sen, a leading scholar in the development field, defines development as the freedom which requires that people be free from poverty, tyranny, and social deprivation. AMARTYA SEN, DEVELOPMENT AS FREEDOM 3 (1999).

${ }^{28}$ Marrakesh Agreement Establishing the World Trade Organization, art II.2 Apr. 15, 1994, 1867 U.N.T.S. 154, ("The agreements and associated legal instruments included in Annexes 1, 2 and $3 \ldots$ are integral parts of this Agreement, binding on all Members.") [hereinafter Marrakesh Agreement].
} 
recently concluded Trans-Pacific Partnership (“TPP"), ${ }^{29}$ that build on the existing regime.

Second, intellectual property rights play an increasingly important role in society. We live in an era where information and technology have tremendous social and financial value. ${ }^{30}$ The food we eat may be the product of genetically modified seeds. ${ }^{31}$ We engage in cultural exchange through social media platforms, such as Twitter, Facebook, Instagram, and others. ${ }^{32}$ We listen to audiobooks, and access and read materials on our electronic tablets. ${ }^{33}$ Children practice mathematics, typing, and other subjects using various online games. ${ }^{34}$ These technologies implicate patents, copyrights, trademarks, and other forms of intellectual property..$^{35}$

Recognizing human development as one of the objectives of intellectual property, rather than as an exception to intellectual property protection, will promote innovation that furthers human development. Both the World Intellectual Property Organization ("WIPO") and the WTO recognize that intellectual property rights are relevant to global development. ${ }^{36}$ In addition, the WTO Agreements provide nations with some degree of flexibility. ${ }^{37}$ While the so-called "TRIPS flexibilities" are useful, reliance on "flexibilities" is only a partial solution. This is because

${ }^{29}$ Trans-Pacific Partnership, signed at Auckland, New Zealand, February 4, 2016 (not yet in force).

30 See Joseph E. STiglitZ, MAKING Globalization WORK 105-06 (2006) (noting that intellectual property and innovation have transformed the lives of everyone in the world); Mario Cimoli et al., The Role of Intellectual Property Rights in Developing Countries: Some Conclusions, in INTELLECTUAL PROPERTY Rights: LEGAL AND ECONOMIC CHALLENGES FOR DEVELOPMENT 503 (Mario Cimoli et al. eds., 2014).

${ }^{31}$ See, e.g., Bowman v. Monsanto Co., 133 S. Ct. 1761 (2013); Karen Kaplan, Why the FDA Doesn't Want You to Say 'GMO', L.A. TIMES (Nov. 20, 2015, 3:00 AM), http://www.latimes.com/science/sciencenow/la-sci-sn-fda-gmo-labeling-20151119-htmlstory.html.

32 Social Networking Fact Sheet, PEW RES. CTR., http://www.pewinternet.org/fact-sheets/socialnetworking-fact-sheet/ (last visited Oct. 19, 2016).

${ }^{33}$ Daniel Berkowitz, Libraries Lend Record Numbers of Ebooks and Audiobooks in 2015, DIGITAL BOOK WORLD (Jan. 5, 2016), http://www.digitalbookworld.com/2016/libraries-lend-record-numbersof-ebooks-and-audiobooks-in-2015/.

${ }^{34}$ See, e.g., Everything You Need to Teach Math, TENMARKS, https://www.tenmarks.com/math (last visited Oct. 19, 2016) (a math educational tool); Learn \& Teach Typing, Free, TYPING.COM, https://www.typing.com/ (last visited Oct. 19, 2016) (a typing educational tool); VOCABULARY SPELLING CITY, https://www.spellingcity.com/ (last visited Oct. 19, 2016) (a vocabulary and spelling educational tool).

${ }^{35}$ See Kristina Sherry, Comment, What Happens to Our Facebook Accounts When We Die?: Probate Versus Policy and the Fate of Social-Media Assets Postmortem, 40 PEPP. L. REV. 185, 208-09 (2012).

${ }^{36}$ See, e.g., World Intellectual Prop. Org. [WIPO], WIPO Development Agenda, at 5, WIPO Publication No. L1015/E, http://www.wipo.int/edocs/pubdocs/en/general/1015/wipo_pub_11015.pdf.

${ }^{37}$ See Doha Declaration, supra note 4, at 9 5. There is much discussion of the "TRIPS flexibilities" in literature. Among others, these include the Article 1 flexibility to determine the appropriate method of implementing the obligations, the purpose and objectives outlined in Articles 7 and 8, as well as exceptions, such as compulsory licensing under Article 31, and transition periods for developing and leastdeveloped countries' under Articles 65 and 66. See generally, TRIPS Agreement, supra note 6. 
Io5

intellectual property protection is the default norm, while human development must be justified in light of these intellectual property obligations.

Part I of this Article provides some background information with regard to the tensions that arose when intellectual property law was harmonized through the WTO and explains the relevance of human development to this conversation. Part II provides theoretical and textual justifications for treating human development as an objective of trade-based intellectual property, while Part III explains the limitations of relying on exceptions to intellectual property protection in trade agreements. Part III also draws on intellectual property theories and trade law objectives to demonstrate that promoting human development is an essential aspect of trade-related intellectual property. Finally, Part IV offers preliminary suggestions for incorporating human development as a core objective of global intellectual property law.

\section{INTELLECTUAL PROPERTY HARMONIZATION \& HUMAN DEVELOPMENT}

\section{A. Enforceable Global Standards}

The expansion of intellectual property rights has been observed domestically as well as internationally ${ }^{38}$ This expansion of rights can be attributed to the increased importance of intangible assets for businesses. ${ }^{39}$ For example, the U.S. government describes the TPP as an accomplishment for American businesses. ${ }^{40}$ Critics contend

38 See Ben Depoorter, The Several Lives of Mickey Mouse: The Expanding Boundaries of Intellectual Property Law, VA. J.L. \& TECH., Spring 2004, at 1, 14 (discussing the expansion of intellectual property rights and the corresponding backlash); see Hannibal Travis, WIPO and the American Constitution: Thoughts on a New Treaty Related to Actors and Musicians, 16 VAND. J. ENT. \&TECH L., 45, 45 (2013) (discussing the expansion of copyright law and the threats posed by the WIPO Treaty on Audiovisual Performances).

${ }^{39}$ See id. at 26 ("As the economic focus has shifted from tangible to intangible products and services ... intellectual property is now an essential component of today's economy. The commercial exchange of intangibles is an increasing percentage of the economy and accounts for a sizeable amount of the GDP of industrialized nations. Intellectual property goods have become a 'crucial set of corporate assets in the new information economy."') (footnotes omitted); Theodore H. Davis, Jr., Combating Piracy of Intellectual Property in International Markets: A Proposed Modification of the Special 301 Action, 24 VAND. J. TRANSNAT'L L. 505, 506 (1991) ("The increasing importance of intellectual property rights in world markets has pushed the issue of their proper legal treatment to the forefront of domestic and international debate."); R. Michael Gadbaw, Intellectual Property and International Trade: Merger or Marriage of Convenience?, 22 VAND. J. TRANSNAT'L L. 223, 225 (1989) (examining "the interaction between trade and intellectual property rights policies through certain key developments in United States law, the General Agreement on Tariffs and Trade (GATT), and the World Intellectual Property Organization (WIPO)"); Robert W. Kastenmeier \& David Beier, International Trade and Intellectual Property: Promise, Risks, and Reality, 22 VAND. J. TRANSNAT'L L. 285, 286-87 (1989) (recounting how the issue of intellectual property came to be included in the Uruguay Round of GATT talks).

${ }^{40}$ See The Trans-Pacific Partnership Overall U.S. Benefits, OfF. U.S. Trade REPRESENTATIVE, https://ustr.gov/sites/default/files/TPP-Overall-US-Benefits-Fact-Sheet.pdf (last visited Aug. 28, 2016). The United States Trade Representative identifies a number of benefits to the TPP, including a more 
that, among other things, the TIP will benefit large corporations rather than the public and that the TPP will change the rules for intellectual property enforcement globally. ${ }^{41}$ These opposing views with regard to trade-based intellectual property obligations reflect the same concerns that arose when the TRIPS Agreement was concluded in $1994 .{ }^{42}$

The TRIPS Agreement remains the foundational agreement in international intellectual property law. For instance, the recently concluded TPP is the most recent major trade agreement that contains intellectual property rules. ${ }^{43}$ Like other agreements since the TRIPS Agreement, the TPP refers to the TRIPS Agreement obligations as the baseline. The same is true of the Anti-Counterfeiting Trade Agreement ("ACTA"), which was concluded in $2011 .{ }^{44}$ This Article will, therefore, focus on the intellectual property obligations that nations have under TRIPS.

The TRIPS Agreement is a multilateral agreement that harmonized global intellectual property standards. ${ }^{45}$ The 1995 merger between trade and intellectual property that came about with the establishment of the WTO marked a shift in global intellectual property law and policy. ${ }^{46}$ At that time, some commentators pointed out that trade regulation and intellectual property have opposite goals because trade regulations primarily aim to remove market barriers while intellectual property laws are often described as creating limited monopolies. ${ }^{47}$ Now, just over twenty years later, intellectual property rules are regularly incorporated into trade agreements. ${ }^{48}$

open Internet, helping small businesses benefit from global trade, stronger protections for workers and for the environment, and a chapter on development. Id.

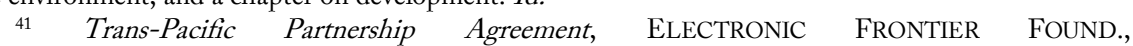
https://www.eff.org/issues/tpp (last visited Oct. 19, 2016).

42 See STIGLITZ, supra note 30, at 105 (explaining that critics of globalization view the TRIPS Agreement as a triumph of corporate interests over the broader interests of the developing world).

43 Trans-Pacific Partnership, ch. 18, Feb. 4, 2016, OFf. U.S. TRAdE RePRESEnTATIVE, https://ustr.gov/sites/default/files/TPP-Final-Text-Intellectual-Property.pdf (last visited Sept. 2, 2016) [hereinafter TPP].

${ }^{44}$ Anti-Counterfeiting Trade Agreement art. 1-2, Oct. 1, 2011, 50 I.L.M. 243 [hereinafter ACTA].

${ }^{45}$ TRIPS Agreement, supra note 6, art. 9-21. Pre-existing agreements, such as the Berne Convention and the Paris Convention, lacked the kind of enforcement mechanism that is available under the WTO. John E. Giust, Noncompliance with TRIPs by Developed and Developing Countries: Is TRIPS Working?, 8 IND. INT’L \& COMP. L. REV. 69, 77 (1997).

${ }^{46}$ See General Agreement on Tariffs and Trade, Oct. 30, 1947, 61 Stat. A-11, 55 U.N.T.S. 194 (demonstrating that WTO's predecessor failed to include intellectual property provisions) [hereinafter GATT 1947].

47 See generally Robert J. Gutowski, Comment, The Marriage of Intellectual Property and International Trade in the TRIPs Agreement: Strange Bedfellows or a Match Made in Heaven?, 47 BUFF. L. REV. 713 (1999) (discussing the "hotly contested global implications" of combining intellectual property with international trade).

${ }^{48}$ See, e.g., ACTA, supra note 44, at 243; TPP, supra note 43, ch. 18, "Intellectual Property". The WTO TRIPS Agreement came into force on January 1, 1995. Overview: The TRIPS Agreement, 
The WTO enforcement mechanism distinguishes the TRIPS Agreement from prior international intellectual property agreements because it gives member states a way to enforce compliance with the WTO obligations. ${ }^{49}$ WTO member states were obliged to comply with the TRIPS Agreement in order to be part of the WTO. ${ }^{50}$ This was an effective strategy for harmonizing global intellectual property standards. All WTO member countries are required to comply with certain minimum obligations for intellectual property that can now be enforced through the WTO dispute resolution process. ${ }^{51}$

These intellectual property standards include, for example, a minimum term of protection of twenty years from the date of filing for patents ${ }^{52}$ and a minimum term of protection of the life of the author plus fifty years for copyright. ${ }^{53}$ In addition, WTO members cannot exclude certain kinds of products from patent protection, ${ }^{54}$ and criminal enforcement and border enforcement is required in certain instances. ${ }^{55}$ These, and other obligations, are referred to as the minimum standards required by the TRIPS Agreement.

The WTO continues to be relevant because it is the only major multilateral trade forum, with most of the countries in the world as parties to the WTO Agreements. ${ }^{56}$

WORLD TRADE ORG., https://www.wto.org/english/tratop_e/trips_e/intel2c_e.htm (last visited Oct. 19, 2016) (stating that the TRIPS Agreement came into effect on January 1, 1995).

${ }^{49}$ See Donald P. Harris, Carrying a Good Joke Too Far: TRIPS and Treaties of Adhesion, 27 U. PA. J. INT'L ECON. L. 681, 725 (2006) (noting the superior enforcement power of the GATT relative to WIPO); J.H. Reichman, Comment, Enforcing the Enforcement Procedures of the TRIPS Agreement, 37 VA. J. INT'L L. 335, 339 (1997) (highlighting that the WTO dispute settlement provisions "put teeth" to intellectual property enforcement at the international level); J.H. Reichman, Universal Minimum Standards of Intellectual Property Protection Under the TRIPS Component of the WTO Agreement, 29 INT’L L. 345, 385 (1995) (discussing the possibility that the failure of one state to enforce its national intellectual property rights could be challenged by foreign nations at the WTO); Peter K. Yu, The International Enclosure Movement, 82 IND. L.J. 827, 862 (2007) (citing the existence of enforcement through the dispute settlement system of the WTO as a significant modification to the international intellectual property regime brought about by TRIPS).

50 See Marrakesh Agreement, supra note 28, art. 4(5); Rachel Brewster, The Surprising Benefits to Developing Countries of Linking International Trade and Intellectual Property, 12 CHI. J. INT'L L. 1, 13 (2011) (noting that " $\mathrm{t}] \mathrm{h}$ he decision to make the WTO a single undertaking was particularly important for the agreement on intellectual property. If states were able to select which trade agreements they wanted to join (as had been the case in earlier GATT rounds), then many developing states would have opted out of the intellectual property agreement."); Rochelle Cooper Dreyfuss \& Andreas F. Lowenfeld, Two Achievements of the Uruguay Round: Putting TRIPS and Dispute Settlement Together, 37 VA. J. INT'L L. 275, 277 (1997) (noting that all members of the WTO must "accept all the agreements negotiated in the Uruguay Round").

51 See Sonali Maulik, Comment, Skirting the Issue: How International Law Fails to Protect Traditional Cultural Marks from IP Theft, 13 CHI. J. INT'L L. 239, 241 (2012) (noting that TRIPS provides "minimum standards for all states party").

52 TRIPS Agreement, supra note 6, art. 33.

${ }^{53}$ Id. art. 12 .

${ }^{54} I d$. art. 27.

${ }^{55} I d$. arts. $51,61$.

${ }^{56}$ Other trade-related intellectual property agreements involve a handful of countries, which makes the WTO the only multilateral forum. For this reason, the WTO agreements remain salient, and it is in 
The United States, however, has entered into a number of bilateral trade agreements, as well as trade and investment agreements that address intellectual property rights. ${ }^{57}$ The European Union has also concluded a number of European Economic Partnerships, which are bilateral trade and development agreements between the European Union and various countries. ${ }^{58}$ Thus, as some scholars have argued, these agreements may limit the so-called TRIPS flexibilities. ${ }^{59}$ This trend renders it all the more critical to acknowledge human development as one of the goals of intellectual property law and to interpret the agreements accordingly.

Since the implementation of TRIPS, nations and scholars have been critical about globally-harmonized intellectual property rules. ${ }^{60}$ One complaint is that the trade-offs, which were the basis for developing countries agreeing to the TRIPS Agreement, never materialized. ${ }^{61}$ There has also been a great deal of criticism of globally harmonized intellectual property standards due to concerns about access to knowledge, access to medicines, bio-piracy and the cultural suitability of these

the interest of most nations to support a multilateral forum rather than bilateral agreements or plurilateral agreements such as ACTA or the TPP. In any event, these subsequent trade agreements must account for the pre-existing obligations of WTO member states.

${ }^{57}$ See, e.g., Understanding Concerning the Protection and Enforcement of Intellectual Property Rights, Phil.-U.S., Apr. 6, 1993, KAV No. 4805; Agreement for the Protection of Copyright, Am. Inst. Taiwan-Cord. Council N. Am. Affairs, July 16, 1993, KAV No. 4021; Agreement Regarding Intellectual Property Rights, China-U.S., Feb. 26, 1995, 34 I.L.M. 881.

58 Economic Partnerships, EUR. COMMISSION, http://ec.europa.eu/trade/policy/countries-andregions/development/economic-partnerships/ (last updated Oct. 13, 2015) ("Economic Partnership Agreements (EPAs) are trade and development agreements negotiated between the E.U. and African, Caribbean and Pacific (ACP) partners engaged in regional economic integration processes."); Fredrick M. Abbott, Trade Costs and Shadow Benefits: EU Economic Partnership Agreements as Models for Progressive Development of International IP Law, in EU BILATERAL TRADE AgreEMENTS AND INTELLECTUAL PROPERTY: FOR BETTER OR WORSE? 159 (2014) ("The developing country partners in the EPAs certainly are aware that they are conceding policy flexibility in accepting the IP provisions, and that by doing so, inter alia, they may be limiting the ability of their domestic industries to make use of EU-generated innovation.") [hereinafter Abbott, Trade Costs and Shadow Benefits].

59 Abbott, Trade Costs and Shadow Benefits, supra note 58, at 159, 170 ("The provisions in the IP chapters that reference sustainable development, transfer of technology and other potentially development-friendly objectives or undertakings may provide some benefits at the margin, but they are not constructed in such a way as to offset concrete costs in areas such as access to pharmaceutical technologies. They appear largely to be in the nature of 'window dressing', more shadow than substance. In this regard, they do not lend themselves as models for the future development of international IP law.").

${ }^{60}$ Peter K. Yu, TRIPs and its Discontents, 10 MARQ. INTELL. PROP. L. REV. 369, 370 (2006).

${ }^{61}$ Uché U. Ewelukwa, Centuries of Globalization; Centuries of Exclusion: African Women, Human Rights, and the "New" International Trade Regime, 20 BERKELEY J. GENDER, L. \& JUST. 75, 105-107 (2005). 
Io5

standards. ${ }^{62}$ In addition, the trend towards greater intellectual property protection through other trade agreements is well entrenched. Some nations continue to seek higher standards of protection through bilateral and plurilateral agreements. ${ }^{63}$

Arguably, large corporations and their industry associations have been successful in pressing for, and obtaining, the type of protection that benefits them. ${ }^{64}$ For instance, the TRIPS Agreement contains a provision that obligates WTO members to provide copyright protection for material that some countries would otherwise not protect, such as computer source codes and compilations of data. ${ }^{65}$ The AntiCounterfeiting Trade Agreement (ACTA), which was signed in 2011, increases enforcement of intellectual property rights at the border, ${ }^{66}$ and the TPP requires signatories to protect information generated by pharmaceutical companies as part of the process of obtaining marketing approvals. ${ }^{67}$

While trade-based intellectual property rights have expanded to cover nontraditional subject matter such as sound trademarks and regulatory data, ${ }^{68}$ attempts to obtain global protection for traditional knowledge, traditional cultural expressions, and folklore have not been successful despite international efforts. ${ }^{69}$ There have even been some well-publicized disputes involving indigenous traditional knowledge following the implementation of minimum standards under the TRIPS

${ }^{62}$ See, e.g., Fredrick M. Abbott, TRIPS in Seattle: The Not-So-Surprising Failure and the Future of the TRIPS Agenda, 18 BERKELEY J. INT'L L. 165, 171 (2000) (noting the patent-related health concerns of developing country members not having access to medicine) [hereinafter Abbott, Trips in Seattle]; Ellen 't Hoen, TRIPS, Pharmaceutical Patents, and Access to Essential Medicines: A Long Way from Seattle to Doha, 3 CHI. J. INT'L L. 27, 28-30 (2002) (describing major criticisms of TRIPS in terms of access to medicine and stating that the safeguards that TRIPS puts in place "increasingly present barriers to medicine access"); Mary W. S. Wong, Toward an Alternative Normative Framework for Copyright: From Private Property to Human Rights, 26 CARDOZO ARTs \& ENT. L.J. 775, 778 (2009) (noting that "international copyright system should place greater emphasis on human rights objectives and norms" with respect to access to knowledge).

63 See Comprehensive Economic and Trade Agreement (CETA), European COMMISSION http://ec.europa.eu/trade/policy/in-focus/ceta/ (last updated Aug. 3, 2016); Chile Free Trade Agreement, OFF. OF THE U.S. TRADE REPRESENTATIVE, https://ustr.gov/trade-agreements/free-tradeagreements/chile-fta/final-text (last visited Oct. 20, 2016); ACTA, supra note 44; TPP, supra note 43.

${ }^{64}$ Amanda Horan, Christopher Johnson \& Heather Sykes, Foreign Infringement of Intellectual Property Rights: Implications for Selected U.S. Industries 3-5 (U.S. Int'1 Trade Comm'n, Office of Indus., Working Paper No. ID-14, 2005) (noting that estimated losses due to foreign copyright piracy in fifty-two selected countries amounted to $\$ 12.5$ billion and that the value of imported goods seized by U.S. Customs and Border Protection for intellectual property rights (IPR) infringement in 2003 amounted to $\$ 94$ million).

${ }^{65}$ TRIPS Agreement, supra note 6, art. 10.

${ }^{66}$ ACTA, supra note 44, art. 28.

${ }^{67}$ TPP, supra note 43 , art. 18.50 .

${ }^{68} I d$. at arts..18.1,18.50.

${ }^{69}$ See World Intel. Prop. Org., Intergovernmental Comm. on Intel. Prop. \& Genetic Res., Trad. Knowledge \& Folklore, GRTKF/IC/14/12 at 27, 66 (Oct. 1, 2009). The TPP, however, unlike TRIPS or ACTA, does acknowledge traditional knowledge. See TPP, supra note 43, art. 18.16. 
Agreement ${ }^{70}$ including those relating to the use of the hoodia cactus plant, neem, and turmeric spice. ${ }^{71}$

The World Intellectual Property Organization ("WIPO") has been working on protection for traditional knowledge for some time, but an agreement has not been reached. ${ }^{72}$ As the WIPO explains, working out the details of such an instrument has been challenging. ${ }^{73}$ Nonetheless, some nations have implemented legislation to protect traditional knowledge and cultural practices at the domestic level. ${ }^{74}$ This includes herbal medicinal practices as well as cultural artwork, such as native totem poles, or songs. ${ }^{75}$

For many, the lack of protection for traditional knowledge underscores the inequities of the intellectual property system. ${ }^{76}$ For example, in Peru, the maca plant

70 Olufunmilayo B. Arewa, TRIPs and Traditional Knowledge: Local Communities, Local Knowledge, and Global Intellectual Property Frameworks, 10 MARQ. INTELL. PrOP. L. REV. 155, 16465 (2006) ("The adoption of the TRIPs Agreement and common minimum global standards for intellectual property frameworks for Members of the WTO has led to increasing debate and dialogue about the lack of protection for local knowledge under TRIPs."); Antony Barnett, In Africa the Hoodia Cactus Keeps Men Alive. Now its Secret is 'Stolen' to Make us Thin, GuARDiAn (June 17, 2001 6:41), https://www.theguardian.com/world/2001/jun/17/internationaleducationnews.businessofresearch; see generally. Janewa OseiTutu, $A$ Sui Generis Regime for Traditional Knowledge: The Cultural Divide in Intellectual Property Law, 15 MARQ. INTELL. PROP. L. REV. 147 (2011).

71 Bio-piracy of Traditional Knowledge, Traditional KnOWLEdge Digital LibR., http://www.tkdl.res.in/tkd1/langdefault/common/Biopiracy.asp (last visited Oct. 20, 2016); Pills, Patients and Profits, BBC WORLD SERV., http://www.bbc.co.uk/worldservice/specials/1718_pills/page3.shtml (last visited Oct. 20, 2016).

72 Id. See generally Intergovernmental Committee (IGC), WORLD InTEL. Prop. ORG., http://www.wipo.int/tk/en/igc/ (last visited Oct. 20, 2016); Traditional Knowledge and Intellectual Property Background Brief, WORLD INTEL. PROP. ORG., http://www.wipo.int/pressroom/en/briefs/tk_ip.html (last visited Aug. 31, 2016) ("Because the existing international intellectual property system does not fully protect traditional knowledge and traditional cultural expressions, many communities and governments have called for an international legal instrument providing sui generis protection.").

${ }^{73}$ Traditional Knowledge and Intellectual Property Background Brief, supra note 72 ("Working out the details is complex and there are divergent views on the best ways forward, including whether intellectual property-type rights are appropriate for protecting traditional forms of innovation and creativity.").

${ }^{74}$ World Intel. Prop. Org., Intergovernmental Committee on Intellectual Property and Genetic Resources, Traditional Knowledge and Folklore, GRTKF/IC/9/INF/4, Annex II (Mar. 27, 2006) (outlining a comparative summary of TCE sui generis legislation); The Copyright Act 2005, No. 690/2005, §§ 17, 44, 64 (Ghana) (providing perpetual protection for Ghanaian folklore); Trade Marks Act 2002, No. 49, § 17 (N.Z.) (prohibiting the registration of marks that are likely to offend a segment of the community, including the Maori); CODE CIVIL No. 27811 (Peru) (providing sui generis protection for indigenous knowledge); Special System for the Collective Intellectual Property Rights of Indigenous Peoples Act 2000, No. 20 (Panama).

75 Traditional Knowledge and Intellectual Property Background Brief, supra note 72.

${ }^{76}$ When patents related to the Maca plant were sought in the U.S. and elsewhere, a number of Peruvian farmers and non-governmental organizations protested the unauthorized use of their traditional knowledge. E. Jane Gindin, Maca: Traditional Knowledge, New World, AMERICAN.EDU (Dec. 2002), $\mathrm{http} / / /$ www1.american.edu/ted/maca.htm ("What is clear to many is that the patenting of maca 
has been used for centuries as a source of food and to make a local health drink. ${ }^{77}$ Among other things, this Peruvian plant, which is known for its fertility enhancing potential, has become attractive on the world market. ${ }^{78}$ Thus, there is more than one United States patent that is based on the use of the maca tuber for health related purposes. ${ }^{79}$ A seemingly simple combination of powdered maca with powdered deer antler has been patented. ${ }^{80}$ Yet, the intergenerational knowledge relating to the use of the maca plant for health purposes cannot be patented. This is because an invention must meet the requirements of novelty, utility, and non-obviousness before it can be protected by patent law. ${ }^{81}$ Since it is widely known that the maca plant has certain health properties, the knowledge is considered to be within the public domain and not, therefore, protectable. Nor is this knowledge currently protectable using other forms of intellectual property. ${ }^{82}$ To some, this reflects a refusal to protect knowledge generated by communities that lack resources. ${ }^{83}$

Businesses must be able to protect their investments and to generate wealth for their shareholders. Yet, it is equally, if not more, important that human development is not undermined, but is also advanced in the process. In addition to facilitating commerce between nations, trade law aims to reduce poverty and promote peace. ${ }^{84}$ Within the trade model, trade-based intellectual property also has the implicit, if not

derivatives amounts to biopiracy, the stealing of biologically-based knowledge for profit that is not shared with those who originated the knowledge."). But see Sean Pager, Traditional Knowledge Rights and Wrongs, 20 VA. J. L. \& TECH. (forthcoming 2016).

${ }_{78}^{77}$ Gindin, supra note 76.

${ }^{78}$ See id.

${ }^{79}$ See, e.g., Maca and Antler for Augmenting Testosterone Levels, U.S. Patent No. 6,093,421 (issued July 25,2000 ), (claiming the process of combining deer antler with maca in certain quantities, orally administered with food to men of a certain age for a two-week period increases testosterone levels).

${ }^{80} \mathrm{Id}$. ("The powdered maca and antler are administered at a weight ratio of maca to antler which is generally in the range of about 1:1 to about 100:1, preferably together in admixture at a weight ratio in the range of about 5:1 to about 50:1. The combination is preferably administered orally, as an admixture of maca and antler in powdered form, more preferably in the form of a tablet or capsule which consists essentially of the admixture. The tablet or capsule can be taken as a dietary supplement, alone or in combination with other foods.").

8135 U.S.C. §§ 102-03 (2012); TRIPS Agreement, supra note 6, arts. 27-34.

${ }^{82}$ Trade secret has been suggested as a form of protection for indigenous traditional knowledge. However, once the information is publicly available, trade secret law is ineffective. See TRIPS Agreement, supra note 6, art. 39; UNIFORM TRADE SECRETS ACT § 5 (Nat'l Conference of Comm'rs of Unif. State Laws 1985).

${ }^{83}$ Tania Bubela \& E. Richard Gold, Introduction: Indigenous Rights and Traditional Knowledge, in Genetic Resources and TRAditional KNOWLEDGe: CASE Studies and CONFLiCTing INTERESTS (Tania Bubela \& E. Richard Gold eds., Edward Elgar, 2012) 1 ("Because of the value of this knowledge, both indigenous peoples and commentators have been concerned about its exploitation by non-indigenous peoples .... These concerns have led to calls for the protection of indigenous or traditional knowledge (TK) and calls for sharing of the benefits derived from the exploitation of the TK. How protection and benefit sharing are to be accomplished, however, is a highly divisive and controversial topic, dividing resource-rich developing countries from those with advanced industrial and research capacity.").

${ }^{84}$ See Marrakesh Agreement, supra note 28, pmbl. 
explicit, objective of promoting human progress. ${ }^{85}$ Unfortunately, the current model of trade-related intellectual property appears to be driven primarily by the financial interests of large multinational corporations. ${ }^{86}$ This creates problems to the extent that the industry objectives are at odds with the goals of promoting peace, sustainable development, ${ }^{87}$ and cooperation. ${ }^{88}$

\section{B. Development as a Concern}

The 1994 merger between intellectual property and international trade was not universally welcomed. ${ }^{89}$ In particular, many observers noted that the standards contained in the TRIPS Agreement were best suited for industrialized countries, and criticized the TRIPS Agreement for its "one size fits all" approach. ${ }^{90}$ Developing countries, in particular, were reluctant to adopt the TRIPS Agreement standards,

\footnotetext{
${ }^{85}$ See infra Part III.

${ }^{86}$ Url Dadush et al., What Companies Want From the World Trading System, WorLd ECON. F. 6-7 (2015), www3.weforum.org/docs/WEF_GAC_Trade_II_2015.pdf.

${ }^{87}$ See, e.g., JoHn H. JaCKSON ET AL., LEgal PROBlems OF INTERNATIONAL ECONOMIC RELATIONS 56-59 (5th ed. 2008) (discussing the theoretical understanding that trade promotes peace). Of course, as the authors note, promoting peace is not the only foreign policy goal of international trade. For instance, U.S. trade policy goals may include building allies or pressuring countries to change their policies. Id. at 59.

${ }^{88}$ Ruth L. Okediji, Public Welfare and the Role of the WTO: Reconsidering the TRIPS Agreement, 17 EMORY INT'L L. REV. 819, 858-59 (2003) (“While the TRIPS negotiations ostensibly took place between state actors, the driving force of the negotiations were private actors, specifically intellectual property industries and their associated lobbies."); Susan K. Sell, Industry Strategies for Intellectual Property and Trade: The Quest for TRIPS, and Post-TRIPS Strategies, 10 CARDOZO J. INT'L \& COMP. L. 79, 81-86 (2002); Joseph E. Stiglitz, Economic Foundations of Intellectual Property Rights, 57 DuKE L.J. 1693, 1694 (2008).

${ }^{89}$ See Xu Yi-Chong, Last Chance? Multilateralism, TRIPS and Developing Countries, in INTERPRETING AND IMPLEMENTING THE TRIPS AGREEMENT: IS IT FAIR? 46 (Justin Malbon \& Charles Lawson eds., 2008).

90 See, e.g., Kembrew Mcleod, Owning Culture: Authorship, Ownership, And INTELLECTUAL PROPERTY LAW 172 (2001) (describing international IP laws as "an unrelenting battle against developing countries to force them to adopt an intellectual property system that is advantageous to these already wealthy countries"); Rachel Brewster, The Surprising Benefits to Developing Countries of Linking International Trade and Intellectual Property, 12 CHI. J. INT'L L. 1, 3 (2011) (describing how developed countries moved negotiations from the WIPO to the WTO in order to achieve minimum standards of intellectual property protection).
} 
Io5

which have been described by many commentators as being ill suited to their economies. ${ }^{91}$

But these same nations were encouraged to adopt higher intellectual property standards on the basis that it would be beneficial for their economies ${ }^{92}$ and would help them increase their foreign direct investment. ${ }^{93}$ Despite these claims, it is not clear that the WTO and its harmonized intellectual property standards have benefitted all countries to the extent promised two decades ago. ${ }^{94}$ Indeed, some observers contend that developing countries are harmed by the current global intellectual property standards. ${ }^{95}$

${ }^{1}$ See, e.g., Jagdish Bhagwati, Afterword: The Question of Linkage, 96 AM. J. INT'L L. 126, 127 (2002) (stating that the TRIPS Agreement "facilitates, even enforces with the aid of trade sanctions, what is in the main a payment by the poor countries (which consume intellectual property) to the rich countries (which produce it)"); Peter M. Gerhart, The Tragedy of TRIPS, 2007 MiCH. ST. L. REV. 143, 167-68 (2007) (arguing that the TRIPS Agreement was the result of uneven bargaining power and results in the perpetuation of wealth disparities); Jerome H. Reichman \& Rochelle Cooper Dreyfuss, Harmonization Without Consensus: Critical Reflections on Drafting a Substantive Patent Law Treaty, 57 DuKE L.J. 85, 94-98 (2007) (noting that TRIPS, in practice, puts a heavy burden on developing countries attempting to compete in knowledge goods); Peter K. Yu, The International Enclosure Movement, 82 IND. L.J. 827, 871 (2007) (arguing that TRIPS requires "poor countries to develop a rich-country intellectual property system").

${ }^{92}$ See generally $\mathrm{Yu}$, supra note 91.

${ }^{93}$ Alan O. Sykes, TRIPs, Pharmaceuticals, Developing Countries, and the Doha "Solution," 3 CHI. J. INT'L L. 47, 59 (2002) (explaining that developing countries accepted TRIPS because "(i) developing countries sought concessions on other matters (such as textiles and agriculture), and believed that the business community in the developed world would not support a package containing these concessions without TRIPs; (ii) developing countries anticipated that in the absence of an intellectual property agreement, large nations such as the United States would take unilateral trade measures anyway to 'punish' nations that did not protect U.S. intellectual property rights; (iii) some developing countries anticipated that intellectual property protection would attract valuable foreign investment and technology transfer; and (iv) some larger developing countries (such as India) recognized that they were significant creators of intellectual property and would reap benefits from the growth of their creative industries."); see also Jagdish Bhagwati, Comment, Services and Intellectual Property Rights, in THE NEW GATT: IMPLICATIONS FOR THE UNITED STATES 112-14 (Susan M. Collins \& Barry P. Bosworth eds., 1994).

${ }^{94}$ See, e.g., Rochelle Cooper Dreyfuss \& Andreas F. Lowenfeld, Two Achievements of the Uruguay Round: Putting TRIPS and Dispute Settlement Together, 37 VA. J. INT'L L. 275, 302 (1997) (suggesting that that TRIPS could have a significantly different impact on developing countries than the other WTO Agreements-in particular, the cost of setting up copyright, trademark, and patenting offices, as well as the costs involved in monitoring and enforcing intellectual property rights is significant); Donald $\mathrm{P}$. Harris, Carrying a Good Joke Too Far: TRIPS and Treaties of Adhesion, 27 U. PA. J. INT'L ECON. L. 681, 685-86 (2006) (asserting that since TRIPS inception, many have concluded that the Agreement is unfair to developing countries).

${ }^{95}$ Harris, supra note 94, at 685 n.8 ("Many of the difficulties created by the Agreement on TradeRelated Aspects of Intellectual Property Rights ("TRIPS") provisions came to light when developing countries sought access to essential medicines protected by patents."); Victor Mosoti, Does Africa Need the WTO Dispute Settlement System?, in TowardS A DeVElopMENT-SuPPORTIVE DispuTE SETTLEMENT System IN THE WTO, 67, at 75 (Sustainable Dev. \& Trade Issues, ICTSD Resource Paper No. 5, 2003) (noting that the costs of WTO membership may outweigh the benefits for some nations); Marci A. Hamilton, The TRIPS Agreement: Imperialistic, Outdated, and Overprotective, 29 VAND. J. TRANSNAT'L L. 613, 614, 616 (1996); A. Samuel Oddi, TRIPS—Natural Rights and a "Polite Form of Economic Imperialism”, 29 VAND. J. TRANSNAT'L L. 415, 459-60 (1996). 
Developing countries have been obligated to implement the TRIPS Agreement intellectual property standards since $2000 .{ }^{96} \mathrm{In}$ recognition of the serious challenges that the least developed countries face, they were given a ten-year grace period before they had to implement their TRIPS Agreement obligations and had until 2005 to comply with this obligation. ${ }^{97}$ Despite the delayed implementation period, the leastdeveloped countries have since sought and obtained two extensions of time, and they now have until 2021 before they have to fully implement the TRIPS Agreement standards. ${ }^{98}$ The WTO members agreed to an additional extension of time with respect to patent protection for medicines in the least-developed countries as well, ${ }^{99}$ giving these countries until 2033 before they must provide full patent protection for pharmaceutical products. ${ }^{100}$ These repeated extensions of time to apply the TRIPS Agreement obligations are a clear indication that the intellectual property standards contained in this agreement were not—and still are not—suitable for countries that have yet to achieve a certain level of industrialization. In effect, the least developed countries are not fully part of the global intellectual property regime. In light of the challenges these developing countries face, it is critical for them to implement intellectual property laws that promote human development.

While developing countries may have special concerns relating to intellectual property, human development as it relates to intellectual property is not exclusively a developing-country problem. All nations feel the negative effects that arise from prioritizing intellectual property rights when these rights interfere with human development. For instance, the disputes I will discuss to illustrate the problem with the current framework are conflicts between industrialized nations. Moreover, it is not clear that high levels of intellectual property protection are necessarily promoting progress in industrialized countries. ${ }^{101}$

${ }^{96}$ See TRIPS Agreement, supra note 6, art. 65.

${ }^{97}$ See id. art. 66.

98 Responding to Least Developed Countries' Special Needs in Intellectual Property, WorLD TRADE ORG., https://www.wto.org/english/tratop_e/trips_e/ldc_e.htm (last updated Oct. 16, 2013) ("This transition period has been extended twice for all LDC members in response to a specific request by the LDC Group. In its decision of 29 November 2005, the TRIPS Council extended the period until 1 July 2013, and on 11 June 2013, it extended this further until 1 July 2021 - or when a particular country ceases to be in the least developed category if that happens before 2021.”).

${ }^{99}$ Council for Trade-Related Aspects of Intellectual Property Rights, Decision of the Council for TRIPS: Extension of the Transition Period Under Article 66.1 of the TRIPS Agreement for Least Developed Country Members for Certain Obligations with Respect to Pharmaceutical Products, WTO Doc. IP/C/73 (Nov. 6, 2015) [hereinafter WTO Decision].

${ }_{100}$ Id. ("Least developed country Members will not be obliged, with respect to pharmaceutical products, to implement or apply Sections 5 and 7 of Part II of the TRIPS Agreement or to enforce rights provided for under these Sections until 1 January 2033, or until such a date on which they cease to be a least developed country Member, whichever date is earlier.").

${ }^{101}$ Jon Matthews, Renewing Healthy Competition: Compulsory Licenses and Why Abuses of the TRIPS Article 31 Standards Are Most Damaging to the United States Healthcare Industry, 4 J. BuS. ENTREPRENEURSHIP \& L., PEPP. U. SCH. L., 119, 119-21 (2010). 
Some leading intellectual property scholars have questioned the commitment to high intellectual property standards in the United States in the face of empirical data which shows that strong intellectual property protections can limit progress. ${ }^{102}$ One well-known scholar, for instance, recently pointed out that the evidence about whether copyrights and patents stimulate innovation and creativity is not conclusive. ${ }^{103} \mathrm{He}$ compared the arguments that favor strong intellectual property protections in the face of inconclusive evidence as a kind of religion or "faith" in current intellectual property law. ${ }^{104}$

Although there is empirical data about the impact of intellectual property rights in industrialized countries, there is relatively limited empirical data about the effect of intellectual property rights in developing countries. ${ }^{105}$ Studies about the relationship between intellectual property and innovation conclude that the effects of patent and copyright protections depend on the extent to which a nation has a high level of domestic research and development ("R\&D"), as well as whether there is an internal market for the products. ${ }^{106}$ For instance, one recent study concluded that if a country does not have its own $R \& D$ infrastructure, or has a small internal market, global investment in R\&D increases if there are strict and uniform intellectual property laws. ${ }^{107}$ Emerging economies, however, experienced greater investment in $\mathrm{R} \& \mathrm{D}$ with less uniform intellectual property regimes. ${ }^{108}$

Most commentators conclude that the research is inconclusive and more studies are needed. ${ }^{109}$ However, there is a consensus that the determination as to an appropriate level of intellectual property protection for a country will depend on

${ }^{102}$ See generally Mark A. Lemley, Faith-Based Intellectual Property, 62 UCLA L. REV. 1328 (2015).

${ }^{103}$ Id. at 1334-35 ("The decidedly ambiguous nature of this evidence should trouble us as IP lawyers, scholars, and policymakers. It is one thing to say in Fritz Machlup's day that we should trust in theory because the evidence isn't in yet. In the absence of evidence, he might well have been right that the best thing to do is maintain the status quo. But it is quite another thing to continue trusting in theory when we have gone out, collected the evidence, and found that it is far from clear that IP is doing the world more good than harm.").

${ }^{104} I d$. at 1337 ("Merges refers to his 'faith' in IP law, and that is exactly the right word. I call this retreat from evidence faith-based IP, both because adherents are taking the validity of the IP system on faith and because the rationale for doing so is a form of religious belief.").

${ }^{105}$ Hassan, Yaqub, and Diepeveen, Intellectual Property and Developing Countries: A Review of the Literature, RAND CORP. (2010), www.rand.org/content/dam/rand/pubs/...RAND_TR804.pdf; Science, Technology and Innovation Strategy for Africa 2024, AFr. UnION COMM'N, http://www.hsrc.ac.za/uploads/pageContent/5481/Science,\%20Technology\%20and\%20Innovation\%20 Strategy\%20for\%20Africa\%20-\%20Document.pdf (last visited Oct. 21, 2016).

${ }^{106}$ Rod Falvey \& Neil Foster, The Role of Intellectual Property Rights in Technology Transfer and Economic Growth: Theory and Evidence, iii, x (U.N. Indus. Dev. Org., Working Paper, 2006), https://www.unido.org/fileadmin/user_media/Publications/Pub_free/Role_of_intellectual_property_rig hts_in_technology_transfer_and_economic_growth.pdf.

${ }^{107}$ Emmanuelle Auriol et al., Intellectual Property Rights Protection in Developing Countries, EUR. Trade STUdY GrouP 5, 10 (2012), http://www.etsg.org/ETSG2012/Programme/Papers/396.pdf.

${ }^{108} \mathrm{Id}$. at 5.

${ }^{109}$ See Hassan, Yaqub, \& Diepeveen, supra note 105, at 48. 
many factors. ${ }^{110}$ At this point, however, it is clear that the implementation of the TRIPS Agreement, which has been in effect since January 1995, ${ }^{111}$ presents significant challenges for developing countries. ${ }^{112}$

Ultimately, the impact of minimum intellectual property standards on different nations will depend, in part, on how the rules are interpreted and applied. If human development is recognized as one of the primary objectives of trade-related intellectual property, the WTO rules can be interpreted and implemented in a manner that allows state parties to these trade agreements to adopt laws and policies that protect intellectual property rights while promoting human development.

Laws and policies that promote human development should not have to be justified solely on the basis that they fall within exceptions to intellectual property protection. ${ }^{113}$ To interpret high levels of protection as the norm, while justifying policies designed to promote human development as the exception, undermines the ability of sovereign nations representing the interests of their domestic constituencies to promote this important and fundamental objective. Trade-based intellectual property regimes are critical to the conversation about human development because, as the next Section will explain, international legal regimes outside the WTO are limited in what they can achieve vis-a-vis the WTO and other trade frameworks, such as the TPP.

\section{Development Over Rights}

This Article advocates a development-based framework rather than a rightsbased framework. As I have discussed elsewhere, advancing human rights is an

${ }^{110}$ Alexi Maxwell \& David Riker, The Economic Implications of Strengthening Intellectual Property Rights in Developing Countries, USITC J. INT'L COM. \& ECON., Nov. 2014, 1, at 8 (concluding that the strength of intellectual property rights in the South do not have an impact on R\&D in the North but can improve the rate of technology transfer to developing nations); Cimoli et al., The Role of Intellectual Property Rights in Developing Countries: Some Conclusions, in INTELleCtUAL PROPERTY RIGHTS: LEGAL AND ECONOMIC CHALlENGES FOR DEVELOPMENT 503, 505, 508 (Mario Cimoli et al. eds., 2014) (stating that other commentators have argued that intellectual property rights have a negative effect on developing countries. They observe that intellectual property rights have not stimulated domestic innovation and that they act as an impediment to development by limiting access to medicines and access to knowledge).

111 Overview: The TRIPS Agreement, WORLD TRADE ORG., https://www.wto.org/english/tratop_e/trips_e/intel2_e.htm (last visited Oct. 21, 2016) (“The TRIPS Agreement, which came into effect on 1 January 1995, is to date the most comprehensive multilateral agreement on intellectual property.").

${ }^{112}$ WTO Decision, supra note 99, at 1 (stating that some developing countries will have until 2033 to implement parts of the TRIP Agreement).

${ }_{113}$ See TRIPS Agreement, supra note 7, at Art. 30 ("Members may provide limited exceptions to the exclusive rights conferred by a patent, provided that such exceptions do not unreasonably conflict with a normal exploitation of the patent and do not unreasonably prejudice the legitimate interests of the patent owner, taking account of the legitimate interests of third parties."). 
Io5

essential aspect of human development. ${ }^{114}$ There is a Declaration on the Right to Development, which offers a rights based approach to development. ${ }^{115}$ In addition, the human-rights basis for intellectual property protection, to the extent one exists, is found in the International Covenant on Economic, Social and Cultural Rights ("ICESCR") as well as in the Universal Declaration of Human Rights (“UDHR"). ${ }^{116}$ However, human development, as discussed in this Article, is not about human rights as such. Instead, the term human development refers to factors such as those used by the United Nations Development Program, rather than a substantive human right to development. ${ }^{117}$

There are a number of international obligations that can be impacted by intellectual property rights. Some scholars and activists have turned to these "counter regimes" as they seek ways to mitigate the effects of the TRIPS Agreement. ${ }^{118}$ The multilateral "counter-regimes" to the WTO include the Convention on Biological Diversity ("CBD"), ${ }^{119}$ human rights instruments, the International Treaty on Plant Genetic Resources ("ITPGR"), ${ }^{120}$ and the United Nations Declaration on the Rights of Indigenous Peoples. ${ }^{121}$ Instruments like the CBD and the UDHR ${ }^{122}$ help to challenge the assumptions about the role of intellectual property rights in the global context. They also highlight non-intellectual property perspectives. The CBD and its Nagoya Protocol aim to conserve biological diversity and ensure the benefits derived from the use of genetic resources are shared fairly. ${ }^{123}$ This could include, for instance, sharing the profits from patented technologies derived from plant genetic

${ }^{114}$ J. Janewa OseiTutu, Human Development as an Intellectual Property Metric, 90 ST. JOHN's L. REV. (forthcoming 2016).

${ }_{115}$ G.A. Res. A/RES/41/128 (Dec. 4, 1986); Ruth L. Gana, The Myth of Development, The Progress of Rights: Human Rights to Intellectual Property and Development, 18 L. \& POL'Y 315, 315-317 (1996).

${ }_{116}$ G.A. Res. 2200A (Dec. 16, 2966) (ICESCR); G.A. Res. A/RES/3/217 A (Dec. 10, 1948) (Universal Declaration of Human Rights) [hereinafter UDHR].

${ }^{117}$ G.A. Res. A/RES/41/128, supra note 115, art. 1.1 ("The right to development is an inalienable human right by virtue of which every human person and all peoples are entitled to participate in, contribute to, and enjoy economic, social, cultural and political development, in which all human rights and fundamental freedoms can be fully realized.").

118 See Laurence R. Helfer, Regime Shifting: The TRIPs Agreement and New Dynamics of International Intellectual Property Lawmaking, 29 YALE J. INT'L L. 1, 6 (2004); see also Chidi Oguamanam, Regime Tension in the Intellectual Property Rights Arena: Farmers' Rights and PostTRIPS Counter Regime Trends, 29 DALHOUSIE L.J. 413, 417, 427, 429, 431 (2006).

${ }_{119}$ United Nations Convention on Biological Diversity, art. 16 (June 5, 1992) [hereinafter CBD].

${ }^{120}$ International Treaty on Plant Genetic Resources for Food and Agriculture, Nov. 3, 2001, 2400 U.N.T.S. 303.

${ }^{121}$ G.A. Res. 61/295 (Sep. 13, 2007).

${ }^{122}$ UDHR, supra note 115.

${ }^{123} \mathrm{CBD}$, supra note 119, art. 1 ("The objectives of this Convention, to be pursued in accordance with its relevant provisions, are the conservation of biological diversity, the sustainable use of its components and the fair and equitable sharing of the benefits arising out of the utilization of genetic resources, including by appropriate access to genetic resources and by appropriate transfer of relevant technologies, taking into account all rights over those resources and to technologies, and by appropriate funding."). 
materials. The UDHR provides that everyone has the right to participate in the cultural life of the community ${ }^{124}$ and a right to an adequate standard of living, including a right to health. ${ }^{125}$ Human rights bodies have also engaged in discussions of intellectual property rights and produced documents that provide their interpretations of these rights. ${ }^{126}$

From an international law perspective, however, there are a number of limitations to these non-trade forums. Even if one were to rely on the Vienna Convention on the Law of Treaties ("VCLT") to interpret WTO obligations in light of other international obligations, ${ }^{127}$ the status of the other agreements vis-a-vis the WTO agreements would tend to lead to prioritizing the WTO intellectual property obligations. This is partly due to the fact that some of the most powerful countries have not ratified the treaties that provide a basis for limiting intellectual property rights. ${ }^{128}$ The United States, for example, voted against the United Nations Declaration on the Rights of Indigenous People, and has not ratified the Convention on Biological Diversity or the International Covenant on Economic Social and

${ }^{124}$ UDHR, supra note 116, art. 27(1) ("Everyone has the right freely to participate in the cultural life of the community, to enjoy the arts and to share in scientific advancement and its benefits.").

${ }^{125}$ Id. art. 25 ("Everyone has the right to a standard of living adequate for the health and well-being of himself and of his family, including food, clothing, housing and medical care and necessary social services, and the right to security in the event of unemployment, sickness, disability, widowhood, old age or other lack of livelihood in circumstances beyond his control.").

${ }^{126}$ General Comment No. 17, Econ. \& Soc, Council, Comm. on Econ., Soc. \& Cultural Rights on its Thirty-Fifth Session, U.N. Doc. E/C.12/GC/17 (2006).

127 Vienna Convention on the Law of Treaties, art. 31(3)(c), opened for signature, May 23, 1969, 1980 U.N.T.S. 332 (stating that treaty obligations should be interpreted in light of "[a]ny relevant rules of international law applicable in the relations between the parties.") [hereinafter VCLT]; Thomas Cottier, Trade and Human Rights: A Relationship to Discover, 5 J. INT'L ECON. L. 111, 113-14 (2002) (discussing the relationship between trade law and human rights law and the need for a more coherent approach to these disparate regimes).

${ }^{128}$ See, e.g., International Covenant on Economic, Social and Cultural Rights, art. 15(1)(c), opened for signature Jan. 3, 1976, 993 U.N.T.S. 3 [hereinafter "ICESCR"]. The U.S. signed the ICESCR in 1977, but has not ratified the agreement. Status of Ratification Interactive Dashboard, U.N. HUM. RTS, OFF. OF THE HIGH COMMISSIONER, http://indicators.ohchr.org/ (last updated Aug. 26, 2016). The United States signed the International Covenant on Civil and Political Rights in 1977, and ratified the agreement in 1992. Id. This means that the U.S. is a party to the agreement and has incorporated the obligations into domestic law. 
Io5

Cultural Rights ("ICESCR"). ${ }^{129}$ The goals of the ICESCR, such as the right to health, and the right to education, for example, are relevant to human development. As compared to the TRIPS intellectual property obligations, the ICESR obligations could be characterized as relatively weak. Importantly, the existence of the WTO enforcement mechanism has the practical effect of prioritizing WTO obligations over those without an enforcement mechanism. Finally, the TRIPS Agreement contains language that could be used to limit deviations from the TRIPS standards. ${ }^{130}$ It is, therefore, essential to re-examine the objectives of trade-based intellectual property.

\section{HuMAN DEVELOPMENT IS INTERNAL TO TRADE-BASED INTELLECTUAL PROPERTY}

Trade agreements can confer legitimacy on particular arrangements by making them the norm. ${ }^{131}$ As a result, these agreements can shape the nature of the arguments that are made, thereby influencing outcomes, even where there appears to be flexibility in these agreements. ${ }^{132}$ This is why there is a need to reframe the conversation, with a view to making human development a norm of intellectual property protection, rather than an exception to the norm. This is a long-term

${ }^{129}$ Declaration on the Rights of Indigenous Peoples, U.N. HuM. RTS, OFF. HigH COMMISSIONER, http://www.ohchr.org/EN/Issues/IPeoples/Pages/Declaration.aspx (last visited Oct. 21, 2016); The U.S., Canada, Australia and New Zealand voted against the Declaration on the Rights of Indigenous Peoples in 2007, Id. List of Parties, CONVENTION ON BIOLOGICAL DivERSITY, https://www.cbd.int/information/parties.shtml (last visited Oct. 26, 2016); Status of Ratification Interactive Dashboard, supra note 128; see also ICESCR, supra note 128, art. 15(1)(c). The ICESCR is the major international human rights agreement that recognizes, among other things, a right to food and housing, a right to the highest standard of mental and physical health, and a right to education. ICESCR, supra note 128, arts. 11-13. These social and cultural rights are positive obligations that states are supposed to implement over time. Id. art. 2.1; General Comment 3: The Nature of the Parties' Obligations, Comm. on Econ., Soc. \& Cultural Rights on its Fifth Session, G.A. Res. 41/128 (Dec. 14, 1990) [hereinafter General Comment 3]. The goals of the ICESCR are relevant to human development. General Comment 3 at If 8 . However, nations may promote human development without formally recognizing some of these social and cultural rights, such as the right to food, as entitlements. For example, the U.S. does not recognize a formal right to education as a natural entitlement, but it makes free primary and secondary school education (although imperfect) available to citizens and residents. See San Antonio Ind. Sch. Dist. v. Rodriguez, 411. U.S. 1, 34-35 (1973).

${ }^{130}$ See, e.g., TRIPS Agreement, supra note 6, art. 8.1.

${ }^{131}$ Andrew Lang, Beyond Formal Obligation: The Trade Regime and the Making of Political Priorities, 18 LEIDEN J. INT'L L. 403, 410 (2005).

${ }^{132} I d$. at 405 ("In the way that it frames and structures discussion of trade issues, trade law shapes the kinds of argument which can be made, who is able to make them, and in what forums they are made. Trade law can change the political dynamic of trade debates, and can orient such debates in particular directions, even where it is formally neutral as to their outcome. This is a model of WTO 'power' in which the WTO is located not so much above national decision-making structures, constraining them from the top down, but rather one in which WTO law is seen as providing the conceptual terrain on which those decisions are made, and thereby determining the contours of the paths down which they travel."). 
strategy, which must be implemented alongside concrete short-term strategies to create effective change.

One might argue that human development imports irrelevant considerations into intellectual property law. Yet, both the WIPO and the WTO recognize that intellectual property rights are relevant to global development. ${ }^{133}$ Further, the notion that intellectual property laws should promote human development can be grounded both in theory and in international legal agreements. This Section of this Article will discuss the theoretical and textual bases for the proposition that trade-related intellectual property should promote human development.

\section{A. As an Intellectual Property Objective}

In the United States, the "progress clause" or "intellectual property clause" of the U.S. Constitution gives Congress the power to enact copyright and patent laws "[t]o promote the Progress of Science and useful Arts" by providing authors time-limited protections for their inventions and creative works. ${ }^{134}$ The predominant understanding of this constitutional provision is that intellectual property laws serve to incentivize innovation by providing a creator with a limited period of market exclusivity. ${ }^{135}$ In other words, patents and copyrights provide economic incentives and rewards for creators. ${ }^{136}$ In this way, patent and copyright laws are said to promote progress. ${ }^{137}$

133 See, e.g., Millennium Development Goal 1: Eradicate Extreme Poverty and Hunger, WorLD INTELL. PROP. ORG., http://www.wipo.int/ipdevelopment/en/agenda/millennium_goals/millennium_goal_1.html (last visited Oct. 21, 2016) ("The intellectual property (IP) system plays an important role in the agricultural sector, in particular in agricultural innovation and food security. In 2009, WIPO established the Program on IP and Global Challenges, with one of its priorities to deal with issues relating to IP and food security."); WORLD INTELlECtUAl PROP. ORG., WIPO INTELLECTUAL PROPERTY HANDBOOK: POLICY, LAW AND USE 163 (2d ed. 2004).

${ }^{134}$ U.S. CONST. art. I, § 8, cl. 8.

135 See, e.g., Diamond v. Chakrabarty, 447 U.S. 303, 307 (1980) (describing the objective of the patent monopoly as existing so that "[ $t]$ he productive effort thereby fostered will have a positive effect on society through the introduction of new products and processes of manufacture into the economy") (quoting Kewanee Oil Co. v. Bicron Corp., 416 U.S. 470, 480 (1974)); Mazer v. Stein, 347 U.S. 201, 219 (1954) ("The economic philosophy behind the clause empowering Congress to grant patents and copyrights is the conviction that encouragement of individual effort by personal gain is the best way to advance public welfare through the talents of authors and inventors in 'Science and useful Arts."); United States v. Paramount Pictures, Inc., 334 U.S. 131, 158 (1948) (“The sole interest of the United States and the primary object in conferring the [copyright] monopoly lie in the general benefits derived by the public from the labors of authors.' It is said that reward to the author or artist serves to induce release to the public of the products of his creative genius.") (quoting Fox Film Corp. v. Doyal, 286 U.S. 123, 127 (1932)).

${ }^{136}$ See SUNDER, supra note 1 , at 3-4.

137 U.S. CONST. art. I, § 8, cl. 8; JANICE M. Mueller, PATENT LAW 21, 23, 26-27, 30 (3d ed. 2009). But see Adam Mossoff, Who Cares What Thomas Jefferson Thought About Patents? 
Despite the predominance of incentive theory, various scholars remind us that the role of intellectual property in society is not as narrow as the prevailing discourse suggests. ${ }^{138}$ With respect to incentive theories, recent studies have demonstrated that authors are motivated by the desire to make a contribution, and not solely by a desire for economic gain. ${ }^{139}$ This desire to contribute supports the idea of property rights serving the public good. In the global context, for example, some constitutions explicitly state that property owners have an obligation to contribute. The German Constitution states: "Property entails obligations. Its use shall also serve the public good." 140

The U.S. Constitution does not refer directly to public benefit. However, it speaks about patent and copyright laws promoting progress. ${ }^{141}$ Scholars have provided various interpretations of "progress." For instance, Malla Pollack explains that progress means that intellectual property laws should promote the dissemination of knowledge and technology. ${ }^{142}$ Alina $\mathrm{Ng}$ suggests that we can be guided by ethics in developing our intellectual property laws, ${ }^{143}$ while Cynthia Ho contends that patents can promote progress that includes a sense of justice. ${ }^{144}$

Some intellectual property scholars have embraced the human flourishing framework developed by Amartya Sen and Martha Nussbaum. ${ }^{145}$ These scholars contend that we should move beyond the narrow law and economics approach to embrace other interpretations of intellectual property law. ${ }^{146}$ Amartya Sen defines

Reevaluating the Patent "Privilege" in Historical Context, 92 CORNELL L. REv. 953 (2007) (explaining the less common view that there is a natural right to patent protection).

138 See, e.g., Betsy Rosenblatt, Belonging as Intellectual Creation, 81 Mo. L. REV. (forthcoming 2017) (discussing the relationship between creativity, intellectual property and a sense of belonging); Sunder, supra note 1, at 323 (advocating a cultural theory of intellectual property that goes beyond economics).

139 Jessica Silbey, The EuREKA MYTH: Creators, InNOVATORS, AND EvERYDAY INTELLECTUAL PROPERTY 2 (2015).

${ }^{140}$ GRUNDGESETZ [GG] [BASIC LAW], art. 14, para. 2, translation at http://www.gesetze-iminternet.de/englisch_gg/englisch_gg.html\#p0079.

${ }^{141}$ U.S. CONST. art. I, § 8, cl. 8; see also supra text accompanying note 83.

${ }^{142}$ Malla Pollack, The Owned Public Domain: The Constitutional Right Not to be Excluded - Or the Supreme Court Chose the Right Breakfast Cereal in Kellogg v. National Biscuit Co., 22 HASTINGS Comm. \& EnT. L.J. 265, 267-91 (2000); Malla Pollack, What is Congress Supposed to Promote?: Defining "Progress" in Article I, Section 8, Clause 8 of the United States Constitution, or Introducing The Progress Clause, 80 NEB. L. REV. 754, 755 (2001).

${ }^{143}$ ALINA NG, COPYRIgHT LAW AND THE PROGRESS OF SCIENCE AND THE USEFUl ARTS 151 (Peter K. Yu ed., 2011).

${ }^{144}$ Cynthia Ho, Do Patents Promote the Progress of Justice? Reflections on Varied Visions of Justice, 36 LOY. U. CHI. L.J. 469, 469 (2005).

${ }^{145}$ SUNDER, supra note 1, at 7 (explaining how her work draws on the works of Amartya Sen and Martha Nussbaum); Margaret Chon, Intellectual Property "from Below": Copyright and Capability for Education, 40 U.C. DAVIS L. REV. 803, 810 (2007) ("The third and final aspect of distributive justice related to IP ponders the general question whether growth-led economic development necessarily contributes to human development, both within and across nations.").

146 SUNDER, supra note 1, at 25 ("I offer three critiques of the narrow intellectual-property-asincentives understanding: (1) it fails descriptively as a comprehensive account of extant legal doctrine, (2) 
development as "expanding the real freedoms that people enjoy." 147 This means that people should be free from tyranny and should enjoy economic opportunities as well as things such as good health and education. ${ }^{148}$ Martha Nussbaum advocates a "capabilities approach" to development, which she distinguishes from the "human development approach," although the terms are used interchangeably. ${ }^{149}$ Nussbaum's approach treats each individual as an end, focusing on choice and freedom. ${ }^{150}$ Like Sen, Nussbaum's capabilities approach emphasizes individual choice. ${ }^{151}$

Drawing on Sen's and Nussbaum's notions of "development," Margaret Chon proposes a distributive justice approach to global intellectual property. ${ }^{152}$ Chon's distributive justice analysis encompasses various factors, one of which is human development as defined by the United Nations Millennium Development Goals. ${ }^{153}$ She adopts the human capabilities approach and considers human rights instruments in analyzing the role of copyright in education. ${ }^{154}$ Madhavi Sunder takes a somewhat different approach from Chon, arguing that culture, including the promotion and

it fails prescriptively as the exclusive basis for deciding the important intellectual property conflicts of the day, and (3) it fails to capture fully the dynamics of cultural creation and circulation.").

${ }^{147}$ AMARTYA SEN, DEVELOPMENT AS FREEDOM 3 (1999).

${ }^{148} I d$. at $3,5$.

${ }^{149}$ Martha C. Nussbaum, CREating Capabilities: The Human Development

APPROACH 17-18 (2001). Nussbaum sees capabilities as broader than human development because this can accommodate animals in addition to humans. $I d$. at 18.

${ }^{150} \mathrm{Id}$.

${ }^{151} I d$. ("In other words, the approach takes each person as an end, asking not just about the total or average well-being but about the opportunities available to each person

${ }^{152}$ Chon, supra note 145 , at 805,810 ("The third and final aspect of distributive justice related to IP ponders the general question whether growth-led economic development necessarily contributes to human development, both within and across nations."); id. at 834 ("I have suggested that a substantive equality principle is needed in global IP norm-setting and norm-interpreting activities in order to facilitate access to essential information goods. This principle would be drawn from the key term 'development' in relevant international IP foundational documents.").

${ }^{153} I d$. at 815-16 ("However, a key difference between an approach from below and other critiques of the current IP balance is its emphasis on distributive justice outcomes. The perspectives and actions of the least empowered among us are included in more than just a formal equality sense in shaping a normative legal agenda. Rather, an approach from below explicitly shapes IP outcomes with respect to knowledge goods by specific groups, in this case, users in developing countries, for specific goals, which could include innovation, access, and affordability. At least for purposes of this Article, these goals also include basic human development as defined by the Millennium Development Goals.").

${ }^{154} I d$. at 818 ("To flesh out a from below approach to IP, I focus on the content of development as applied to copyrights and human capability for education. While at first blush, copyrights may seem to have less to do with public health and welfare than do patents, there is a very strong demonstrable link between education and public health measures such as fertility, infant and child mortality, and adult morbidity and mortality. Moreover, arguably a right to education is embodied in various human rights documents, which form the legal basis for a human capability approach to the question of copyright on educational materials."). 
Io5 dissemination of artistic and technological goods, is an aspect of human development. ${ }^{155}$

This Article builds on the work of such scholars, turning to theories of international trade to recast the role of trade-based intellectual property in promoting progress and innovation as promoting human progress that includes, but is not limited to, economic development. ${ }^{156}$ Human development does not need to be justified through "exceptions" to intellectual property protection because it is a central objective of trade-related intellectual property. It must be a factor in the interpretation and application of our trade-based intellectual property obligations. Admittedly, terms like "human development" can be somewhat nebulous. However, promoting "human development" or "human progress" is arguably no less clear than the U.S. constitutional language about promoting "the progress of science and the useful arts." ${ }^{157}$ As the next Section will explain, there are ways to define and assess human development, just as there are ways to define and assess "progress."

\section{B. As Progress and Innovation}

What do we mean when we speak of "progress" or "innovation" or "development?" "Progress" is defined as: "a forward or onward movement (as to an objective or to a goal)," "gradual betterment," and "the progressive development of mankind." ${ }^{158}$ It is also defined as "development towards a better, more complete, or more modern condition."

To progress or develop can be the same or very similar. "Develop" is defined as "to or grow or cause to grow or become larger and more advanced."159 "Development" is "the process of developing or being developed," "a specified state of growth or advancement." 160

Advance and progress are synonyms. ${ }^{161}$ Innovation is not synonymous with development, but it is related. To "innovate" is "to do something in a new way; to have new ideas about how something can be done." 162 When we speak of promoting progress in intellectual property, we tend to speak of innovation.

${ }^{155}$ SUNDER, supra note 1 , at 7.

156. Alina Ng has argued that there are other ways to conceive of "progress." See NG, supra note 151, at 123 ("We have unwittingly permitted economics rather than ethics to be the governing influence upon the behavior of those creating, producing, and using literary and artistic work within the copyright system. In many ways, the progress of science and the useful arts works on a very different plane from the one we have constructed through our laws.").

${ }^{157}$ U.S. CONST. art. I, § 8, cl. 8.

158 Progress, Webster's NinTH New Collegiate Dictionary (1988).

${ }^{159}$ Develop, CONCISE OXFORD ENGLiSh DiCTIONARY (2008).

${ }^{160}$ Id. Development ("a specified state of growth or advancement").

${ }^{161}$ Advance, Webster's New Riverside Dictionary (1984); Progress, Concise Oxford ENGLISH DICTIONARY (2008).

${ }^{162}$ Innovate, WEBSTER'S NEW RIVERSIDE DICTIONARY 
Human innovation and progress can take into account economic progress, as well as scientific, social, educational, and artistic progress ${ }^{163}$ Scientific progress can, and should, be promoted along with human progress. Indeed, these two forms of progress are interrelated and should occur simultaneously. In the international context, where divergent cultural values prevail, exclusive reliance on reward theory ${ }^{164}$ to explain and assess intellectual property rules is inadequate. The effects of intellectual property protection are not limited to promoting or hindering economic development or rewarding the creator for her work. Rather, as much of the critique of strong intellectual property rights has demonstrated, intellectual property rights can affect educational development, health, and culture.

Indeed, the United Nations Human Development Index ("HDI") recognizes that economic progress alone is not an adequate measure of progress. ${ }^{165}$ Human development is multi-faceted, and includes progress in terms of health, education, and economic wealth. ${ }^{166}$ Hence, the focus here is not on the provisions in the TRIPS Agreement that allow nations some freedom to implement their intellectual property obligations as they choose. Rather, the argument is that compliance with intellectual property standards should promote human progress because it is an objective of intellectual property law to stimulate innovation and progress, broadly defined. ${ }^{167}$

Trade-related intellectual property has been a reality for the past twenty years. If countries are socially, politically, and economically unstable while wealth is increasingly concentrated in the hands of a few, ${ }^{168}$ trade agreements become a basis for protest rather than a model for global peace. ${ }^{169}$ Trade-related intellectual property law should be developed, interpreted, and enforced in a manner that is consistent with trade law objectives of advancing peace and stability, as well with intellectual

${ }^{163}$ Human Development Index, supra note 26.

164 Jeanne C. Fromer, Expressive Incentives in Intellectual Property, 98 VA. L. REV. 1745, 1787 (2012) (explaining reward theory justifies patent and copyright protection as a reward for the innovators efforts and contribution).

${ }^{165}$ Human Development Index, supra note 26 ("The Human Development Index was created to emphasize that people and their capabilities should be the ultimate criteria for assessing the development of a country, not economic growth alone.").

${ }^{166} I d$.

${ }^{167}$ JEREMY DE BeER ET AL., InNOVATION AND INTELleCtual Property: COllaborative DYNAMICS IN AFRICA 1 (Jeremy de Beer et al. eds., 2014) ("Human development, including not just economic growth but also the capability for longer, healthier and more fulfilling lives, depends on innovation and creativity.").

${ }^{168}$ This is not to suggest that intellectual property obligations are responsible for the instability. However, when various political and economic forces lead to a situation of instability, or even the perception - even if it is inaccurate-of decreased prosperity, trade agreements may be targeted. For instance, the anti-trade sentiments have been expressed by Republican presidential candidate Donald Trump. See Nick Corsaniti et al., Donald Trump Vows to Rip up Trade Deals and Confront China, N.Y. TiMES (June 28, 3016), http://www.nytimes.com/2016/06/29/us/politics/donald-trump-tradespeech.html?_r=0.

${ }^{169}$ Abbott, TRIPS in Seattle, supra note 62, at 165-66. 
Io5

property goals of promoting innovation and progress. The next Section will show how human development is an objective of trade law.

\section{As a Trade Objective}

International trade is largely based on the economic theory of comparative advantage. ${ }^{170}$ However, trade liberalization had other important goals beyond the economic benefits. ${ }^{171}$ In addition to promoting open borders and free trade, the WTO goals include contributing to sustainable development, reducing poverty, and promoting global peace and stability. ${ }^{172}$ Development concerns date back to the GATT 1947, which was the predecessor to the WTO. ${ }^{173}$ A more recent trade agreement, the TPP, has a chapter on development, which recognizes the importance of "development in promoting inclusive economic growth" and the "instrumental role" that trade can play in economic growth. ${ }^{174}$

Turning to the WTO agreements, there is textual support for interpreting and enforcing trade-related intellectual property obligations to support human capabilities. Article 31(1) of the Vienna Convention on the Law of Treaties ("VCLT") states that a treaty should be interpreted "in good faith in accordance with the ordinary meaning to be given to the terms of the treaty in their context and in light of its objectives and purpose." 175 The VCLT further provides that the context includes the text, the preamble, the annexes and agreements made in connection with the treaty. ${ }^{176}$

In the preamble to the Agreement Establishing the World Trade Organization, ${ }^{177}$ the parties to the Agreement recognize that, among other things, trade should raise standards of living while promoting sustainable development and

${ }^{170}$ RAJ BHALA, INTERNATIONAL TRADE LAW: INTERDISCIPLINARY THEORY AND PRACTICE 207-08 (3d ed., 2009).

${ }^{171}$ ANDREW T. GuZMan \& JoOst H.B. PAUWELYN, InTERnATIONAL TRADE LAW 28 (2009) ("The creation of GATT in 1947 was, to a great extent, also inspired by non-economic objectives such as preventing further wars.").

${ }_{172}$ World Trade Organization: Overview, WORLD TRADE ORG., https://www.wto.org/english/thewto_e/whatis_e/wto_dg_stat_e.htm ("The WTO's founding and guiding principles remain the pursuit of open borders, the guarantee of most-favoured-nation principle and non-discriminatory treatment by and among members, and a commitment to transparency in the conduct of its activities. The opening of national markets to international trade, with justifiable exceptions or with adequate flexibilities, will encourage and contribute to sustainable development, raise people's welfare, reduce poverty, and foster peace and stability. At the same time, such market opening must be accompanied by sound domestic and international policies that contribute to economic growth and development according to each member's needs and aspirations.").

${ }^{173}$ T. N. Srinivasan, Developing Countries in the World Trading System: From GATT, 1947, to the Third Ministerial Meeting of WTO, 1999, 22 WORLD ECON. 1047, 1047-48 (1999).

${ }^{174}$ TPP, supra note 43, art 23.1.

${ }^{175}$ VCLT, supra note 127 , art. 31(1).

${ }^{176} I d$., art. 31(2).

${ }^{177}$ Marrakesh Agreement, supra note 28, pmbl. 
respecting differing national levels of economic development. ${ }^{178}$ Development, is a key element of the WTO agenda. ${ }^{179}$ As part of the Doha round of negotiations, which started in 2001, the WTO adopted a Development Agenda. ${ }^{180}$ The commitment to development that was agreed by the WTO member states is reflected in the 2001 Doha Declaration. ${ }^{181}$ Paragraph Two of the Doha Declaration explicitly recognizes that "international trade can play a major role in the promotion of economic development and the alleviation of poverty." 182

The WTO members adopted a separate declaration on TRIPS and public health. ${ }^{183}$ Paragraph 17 of the 2001 Doha Declaration emphasizes the importance of implementing TRIPS “in a manner supportive of public health." 184 Paragraph 19 of the Doha Declaration recognizes the need for the WTO to consider the relationship between intellectual property, traditional knowledge and the Convention on Biological Diversity. ${ }^{185}$ The Doha Declaration on the TRIPS Agreement and Public

${ }^{178}$ See id. ("The Parties to this Agreement, Recognizing that their relations in the field of trade and economic endeavor should be conducted with a view to raising standards of living, ensuring full employment and a large and steadily growing volume of real income and effective demand, and expanding the production of and trade in goods and services, while allowing for the optimal use of the world's resources in accordance with the objective of sustainable development, seeking both to protect and preserve the environment and to enhance the means for doing so in a manner consistent with their respective needs and concerns at different levels of economic development ... Agree as follows ....").

${ }^{179}$ See, e.g., World Trade Organization, Fifth Global Review Aid-For-Trade Monitoring Exercise, Reducing Trade Costs for Inclusive, Sustainable Growth, WTO Doc. WT/COMTD/AFT/W/52 (Aug. 7, 2014) (discussing the Fifth Global Review of Aid for Trade's aims to promote sustainable development for developing and least developed countries).
180 The Doha Round, WORLD TRADE ORG., https://www.wto.org/english/tratop_e/dda_e/dda_e.htm\#development ("The Doha Round is the latest round of trade negotiations among the WTO membership. Its aim is to achieve major reform of the international trading system through the introduction of lower trade barriers and revised trade rules. The work programme covers about 20 areas of trade. The Round is also known semi-officially as the Doha Development Agenda as a fundamental objective is to improve the trading prospects of developing countries.") (last visited Oct. 22, 2106).

${ }^{181}$ Doha Declaration, supra note 4, \ 10.

${ }^{182} I d$. $\ 2$ ("We recognize the need for all our peoples to benefit from the increased opportunities and welfare gains that the multilateral trading system generates. The majority of WTO members are developing countries. We seek to place their needs and interests at the heart of the Work Programme adopted in this Declaration.").

${ }^{183}$ World Trade Organization, Declaration on the TRIPS Agreement and Public Health, WTO Doc. WT/MIN(01)/DEC/2 (Nov. 20, 2001) [hereinafter Doha Declaration on Health].

${ }^{184}$ Doha Declaration, supra note 4, at 17 ("We stress the importance we attach to implementation and interpretation of the Agreement on Trade-Related Aspects of Intellectual Property Rights (TRIPS Agreement) in a manner supportive of public health, by promoting both access to existing medicines and research and development into new medicines and, in this connection, are adopting a separate declaration.").

${ }^{185}$ Id. ๆ 19 ("We instruct the Council for TRIPS... to examine, inter alia, the relationship between the TRIPS Agreement and the Convention on Biological Diversity, the protection of traditional knowledge and folklore, and other relevant new developments raised by members pursuant to Article 71.1. 

TRIPS Agreement. ${ }^{186}$ These include exceptions for compulsory licensing, national emergencies, and the flexibility to determine when an intellectual property right has been exhausted. ${ }^{187}$ These clear statements by WTO member states provide the context for interpreting trade obligations in a manner that supports human development. ${ }^{188}$ Trade can, and should, play a role in alleviating poverty and raising standards of living. ${ }^{189}$

Further, the WTO has explicitly acknowledged the relationship between its objectives in facilitating trade and development and the United Nations Millennium Development Goals. ${ }^{190}$ The WTO identifies Millennium Development Goal ("MDG") 8 as particularly pertinent to the WTO agenda; the goal of which is to develop a global partnership for development. ${ }^{191}$ Each MDG goal includes a number of targets. One of the targets of MDG 8 is to "develop further an open, rule-based, predictable, nondiscriminatory trading and financial system ([including] a commitment to good governance, development, and poverty reduction)."192

There is, therefore, a basis to conclude that human development is part of the broader trade agenda. As the next Section will discuss, the language of the TRIPS Agreement supports the thesis that global intellectual property should promote human development.

In undertaking this work, the TRIPS Council shall be guided by the objectives and principles set out in Articles 7 and 8 of the TRIPS Agreement and shall take fully into account the development dimension.").

${ }^{186}$ Doha Declaration on Health, supra note 183, at I 5; see also Doha Declaration, supra note 4, at ๆ 4.

${ }^{187}$ Doha Declaration on Health, supra note 183, at I 5; see also Doha Declaration, supra note 4, at I 5 (describing flexibilities and explaining that once an intellectual property right is exhausted, the right can no longer be used to control the movement of the good); TRIPS Agreement, supra note 6, art. 6 (providing that each member state will determine its own rules of exhaustion).

${ }^{188}$ But see Peter K. Yu, The Objectives and Principles of the TRIPS Agreement, 46 Hous. L. REV. 979, 997 ("Those who view the Declaration as a statement of fact are unlikely to impute to Articles 7 and 8 any new or elevated legal status. In fact, one could make a strong argument that the Doha Declaration was a mere restatement of Article 31.1 of the Vienna Convention .... .) (internal footnotes omitted).

${ }^{189}$ Doha Declaration, supra note 4, $\mathbf{\Upsilon} 2$.

${ }_{190}$ Millennium Development Goals, The WTO and the Sustainable Development Goals, WORLD TRADE ORG., https://www.wto.org/english/thewto_e/coher_e/mdg_e/mdg_e.htm (last visited Oct. 22, 2106) ("The United Nations Millennium Development Goals (MDGs) are eight international development goals that all 192 members and a number of international organizations have agreed to achieve by the year 2015 to end poverty. They include reducing extreme poverty, reducing child mortality rates, fighting disease epidemics, such as HIV/AIDS, and creating a global partnership for development. The main goal that concerns the WTO is MDG 8, building a global partnership for development .... However, WTO activities are also relevant to other goals, such as MDG 1, whose aim is to eradicate extreme poverty and hunger. In fact, the MDGs cannot be seen in isolation: they are all interconnected.").

${ }^{191} I d$.

192 Goals, Targets and Indicators, U.N. MillenNIUM PROJECT, http://www.unmillenniumproject.org/goals/gti.htm (last visited Oct. 22, 2016). 


\section{As a Trade-Based Intellectual Property Objective}

Intellectual property laws that support human development can be further justified based on the text of the TRIPS Agreement, the Doha Declaration, and the Doha Declaration on Health. The TRIPS Agreement is an annex to the Agreement Establishing the WTO. ${ }^{193}$ Thus, the intellectual property obligations contained therein must be interpreted in light of the objectives of the WTO, in addition to the specific objectives of the TRIPS Agreement. The TRIPS Agreement preamble situates these global intellectual property standards within the context of trade law and the desire to reduce barriers to trade ${ }^{194}$ Hence, minimum intellectual property rules that nations implement as part of this trade regime should contribute to raising standards of living, while respecting different levels of development.

As various scholars have noted, the objectives and principles of the TRIPS Agreement are critical to its proper interpretation. ${ }^{195}$ In accordance with the VCLT, the obligations under the TRIPS Agreement should be interpreted in light of the objectives of the agreement. ${ }^{196}$ These international law interpretative principles have enabled commentators to promote the use of what has come to be known as the "TRIPS flexibilities" under Articles 7 and 8 of TRIPS as well as the exceptions to intellectual property protection available under the TRIPS Agreement. ${ }^{197}$

Article 7, which sets out the "objectives" of TRIPS, requires a balancing of rights and obligations. ${ }^{198}$ It describes intellectual property as having the objective of contributing to the "promotion of technological innovation and to the transfer and dissemination of technology, to the mutual advantage of producers and users of technological knowledge and in a manner conducive to social and economic welfare, and to a balance of rights and obligations." 199 This balancing test is one of the interpretative tools for the TRIPS Agreement obligations.

The principles of the TRIPS Agreement are found in Article 8. Article 8.1 of TRIPS, is often cited, along with Article 7 of TRIPS, as part of the "flexibilities"

${ }^{193}$ See Marrakesh Agreement, supra note 28, Annex IC.

194 TRIPS Agreement, supra note 6, pmbl. ("Desiring to reduce distort and impediments to international trade, and taking into account the need to promote effective and adequate protection of intellectual property rights, and to ensure that measures and procedures to enforce intellectual property rights do not themselves become barriers to legitimate trade ....").

${ }^{195} \mathrm{Yu}$, supra note 196, at 1018 ("Articles 7 and 8, which outline the objectives and principles of the TRIPS Agreement, constitute 'a central piece for the implementation and interpretation of the TRIPS Agreement."').

${ }^{196}$ See VCLT, supra note 175 , art. 31.

${ }^{197} I d$. art. 31(1)-(2) ("A treaty shall be interpreted in good faith in accordance with the ordinary meaning to be given to the terms of the treaty in their context and in the light of its object and purpose . ... The context for the purpose of the interpretation of a treaty shall comprise, in addition to the text, including its preamble and annexes....").

198 TRIPS Agreement, supra note 6, art. 7.

${ }^{199} I d$. 
Io5

available to protect public health. Article 8.1 allows WTO members to adopt laws and regulations that "promote the public interest." ${ }^{200}$ Further, it allows WTO members to enact laws to "protect public health and nutrition." ${ }^{201}$ But it also requires that any such laws and regulations must be "consistent with the provisions of this Agreement." 202

If intellectual property protection is interpreted as being at odds with the public interest, then Article 8 potentially limits what can be done in the public interest. Such an interpretation would also render Article 8 of TRIPS virtually meaningless. If intellectual property rights are understood as having the objective of advancing human development, however, there will be no conflict between protecting intellectual property and protecting the public interest as it relates to human development. This would include laws and policies designed to "protect public health and nutrition." ${ }^{203}$

The "TRIPS flexibilities" are valuable insofar as they encourage us to contemplate the balancing of interests in the global context. Yet, the language of "flexibilities" suggests that prioritizing aspects of human development, such as human health, somehow requires a deviation from intellectual property protection. Admittedly, there are clear exceptions to intellectual property protection, such as compulsory licensing. ${ }^{204}$ However, whether or not intellectual property rights will compete with human development objectives or promote human development is a matter of interpretation.

If prioritizing intellectual property protection is the norm, then interpretations of intellectual property obligations that aim to advance human development by limiting protection may be seen as diverging from the primary goals of intellectual property law. Human development objectives, such as discouraging smoking, or making generic drugs available as soon as the patent expires, can only be accommodated as a concession. Furthermore, the language of "exception" suggests that the intellectual property producer relinquishes some kind of entitlement for the benefit of the public. In other words, intellectual property protection becomes the default norm and any deviation from the norm must be justified.

The Doha Declaration, the Doha Declaration on Health, and the principles and objectives of the TRIPS Agreement all suggest that intellectual property rights should not interfere with human development objectives, like protecting human health. As this Article contends, not only should intellectual property rights not interfere with human development, but intellectual property laws and policies that promote human development are consistent with the TRIPS Agreement, and with the objectives of the WTO.

${ }^{200} I d$. art. 8(1).

${ }^{201} \mathrm{Id}$.

${ }^{202} I d$. (emphasis added).

${ }^{203} \mathrm{Id}$.

${ }^{204}$ Id. art. 21. 


\section{THE LIMITATIONS OF “EXCEPTIONS” AND “FLEXIBILITIES”}

The prevailing view in the United States is that patent and copyright laws provide incentives to creators and innovators for the purpose of stimulating innovation. ${ }^{205}$ Trademarks provide an efficient way for consumers to identify and distinguish products. ${ }^{206}$ In return, intellectual property owners are able to recover costs and obtain some financial reward for their contribution. ${ }^{207}$ This utilitarian approach to intellectual property is also reflected in the language of trade agreements such as the TRIPS Agreement. ${ }^{208}$

The success of the intellectual property system tends to be measured by the number of patents, trademarks, and copyrights, and the revenue generated therefrom. ${ }^{209}$ The underlying assumption with such approaches is that more intellectual property rights leads to more innovation. ${ }^{210}$ Thus, trade-based intellectual property obligations have been interpreted in a way that treats private economic gain as a primary objective of intellectual property protection. It also supports a model that favors more expansive intellectual property protection over limitations to intellectual property. This is one way to view intellectual property rights, but, as this Article argues, this is too narrow a vision of the role and purpose of intellectual property protection. While financial rewards for the creator are important, they are only part of the story.

205 See, e.g., U.S. CONST. art. I, § 8, cl. 8.; Diamond v. Chakrabarty, 447 U.S. 303, 307 (1980) (describing the objective of the patent monopoly as existing so that "[t]he productive effort thereby fostered will have a positive effect on society through the introduction of new products and processes of manufacture into the economy") (quoting Kewanee v. Bicron, 416 U.S. 470, 480 (1974)); United States v. Paramount Pictures, Inc., 334 U.S. 131, 158 (1948) ("'The sole interest of the United States and the primary object in conferring the [copyright] monopoly lie in the general benefits derived by the public from the labors of authors.' It is said that reward to the author or artist serves to induce release to the public of the products of his creative genius.") (quoting Fox Film Corp. v. Doyal, 286 U.S. 123, 127 (1932)).

${ }^{206}$ See, e.g., 15 U.S.C. $\$ 1127$ (2006) (the term trademark includes a mark used or intended to be used by a person "to identify and distinguish his or her goods, including a unique product, from those manufactured or sold by others and to indicate the source of the goods, even if that source is unknown"); Trademarks, WORLD INTELL. PROP. ORG., http://www.wipo.int/trademarks/en/ ("A trademark is a sign capable of distinguishing the goodsor services of one enterprise from those of other enterprises.") (last visited Oct. 22, 2016).

${ }^{207}$ See U.S. CONST. art. I, § 8, cl. 8.

${ }^{208}$ See TRIPS Agreement, supra note 6, pmbl.

${ }^{209}$ See, e.g., World Intellectual Prop. Org. Statistics Database [WIPO], WIPO Indicators, at 6, WIPO Publication No 941E (2015), www.wipo.int/edocs/pubdocs/en/wipo_pub_941_2015.pdf [hereinafter WIPO Indicators]; see also DE BEER ET AL., supra note 167, at 43, 72.

${ }^{210}$ See supra note 205. 
There have been a number of WTO disputes relating to intellectual property, but only a few of them were fully adjudicated. ${ }^{211}$ In these disputes, where intellectual property protection has been balanced against some other societal interest, protecting intellectual property has been given priority. As a result, nations have had to justify their actions as the exception to the rule that intellectual property rights must be protected. This reflects an interpretation and application of the TRIPS Agreement obligations that treats human development and intellectual property protection as incongruent.

The WTO intellectual property disputes that have clearly raised human development issues include the Canada Pharmaceuticals case, the India Generics case, and the ongoing Australian Plain Packaging Legislation dispute. ${ }^{212}$ Although the Canada Pharmaceuticals case is more than a decade old, it remains the only WTO panel decision that weighed public health considerations against the rights of the intellectual property owner. ${ }^{213}$ I will first discuss the Canada Pharmaceuticals case before turning to an analysis of other disputes.

\section{A. Canada Pharmaceuticals: A Failed Attempt}

The European Union ("E.U.") initiated this complaint against Canada, ${ }^{214}$ and a number of other countries joined as third parties. ${ }^{215}$ The legal issues in the Canada Pharmaceuticals case were primarily about the correct interpretation of TRIPS Agreement obligations. ${ }^{216}$

The Canadian law at issue allowed generic drug manufacturers to engage in research for the purpose of meeting regulatory requirements for drug approval. This was known as the regulatory review exemption. ${ }^{217}$ Most countries agreed that this

${ }^{211}$ WTO Member states can bring disputes before the WTO in accordance with the Understanding on the Settlement of Disputes. The process starts with consultations, after which, if the dispute is not resolved, it can be decided through litigation. The court in WTO proceedings is referred to as the Panel or, on appeal, the Appellate Body.

${ }^{212}$ Panel Report, Canada-Term of Patent Protection, WTO Doc. WT/DS170/1 (May 10, 1999) [hereinafter Canada Panel Report]; Request for Consultation by India, European Union and a Member State-Seizure Of Generic Drugs in Transit, WTO Doc. WT/DS408/1 (May 19, 2010); Request for Consultations by Ukraine, Australia-Certain Measures Concerning Trademarks and Other Plain Packaging Requirements Applicable to Tobacco Products and Packaging, WTO Doc. WT/DS434/1 (Mar. 13, 2012).

${ }^{213}$ Panel Report, Canada-Patent Protection of Pharmaceutical Products, § IV(A)(5), WTO Doc. WT/DS114/R (Mar. 17, 2000) [hereinafter Canada, Patent Protection of Pharmaceuticals].

${ }^{214}$ The party to this dispute was the European Communities ("E.C.") and their member states. Id. Following the Treaty of Lisbon in 2009, the E.C. became the European Union. I will refer to the E.C. as the E.U., which is the current iteration of the organization.

${ }^{215} \mathrm{Id}$. $\S \mathrm{V}$.

${ }^{216} I d$. $\S \mathrm{I}$.

${ }^{217}$ Id. § II(b). 
was an acceptable exception to the patent right. ${ }^{218}$ In addition, the Canadian law allowed companies to manufacture the patented drug six months before the patent expired. This enabled generic drug manufacturers to make the lower cost generic version of the drug available for sale as soon as the patent expired. This was the "stockpiling exception." ${ }^{219}$ Brazil, India, Cuba, and Israel viewed the Canadian law as consistent with the TRIPS obligations. ${ }^{220}$ The United States ${ }^{221}$ and Japan ${ }^{222}$ argued against the stockpiling exception.

The E.U. contended that the Canadian law violated the TRIPS Agreement because it allowed persons other than patent owners to produce, but not sell, the patented product six months before the patent expired without paying fees to the patent holder. ${ }^{223}$ Article 28 of TRIPS provides that the patent owner shall have the exclusive right to make, use, and sell the patented invention, ${ }^{224}$ and Article 33 requires the term of protection to be twenty years from the date of filing. ${ }^{225}$

Canada defended its law as a limited exception to the patent right, as permitted under Article 30 of the TRIPS Agreement. ${ }^{226}$ Article 30 allows limited exceptions to the patent right if they do not "unreasonably conflict with a normal exploitation of the patent and do not unreasonably prejudice the legitimate interests of the patent owner," taking into account the interests of third parties. ${ }^{227}$ Canada argued that the stockpiling provision did not interfere with the normal exploitation of the patent because the patent owner would not have to compete on the market with third parties until after the patent had expired. ${ }^{228}$ Furthermore, Canada argued that the law sought to protect public health by promoting access to lower cost generic medications as soon as the patent expired, consistent with Articles 30, 7 and 8 of TRIPS. ${ }^{22}$ These three Articles were the "exceptions" and "flexibilities" to the patent right. In effect, this argument acknowledged that intellectual property could be prioritized while public health was to be justified as an exception.

The Panel concluded that the stockpiling exception conflicted with Canada's obligations under the TRIPS Agreement. ${ }^{230}$ The Panel reached this conclusion by

${ }^{218} I d . \S \operatorname{IV}(\mathrm{B})(1)(\mathrm{b})$.

${ }^{219} \mathrm{Id}$. $\S \mathrm{VII}(\mathrm{A})(2)$.

${ }^{220} I d$. $\S \mathrm{V}$.

${ }^{221} I d$.

${ }^{222} I d$.

${ }^{223}$ Id. § IV(A); TRIPS Agreement, supra note 6, arts. 28.1, 33.

${ }^{224}$ TRIPS Agreement, supra note 6, art. 28.1. (prohibiting "third parties not having the owner's consent from the acts of: making, using, offering for sale, selling, or importing” the patented product or process).

${ }^{225} \mathrm{Id}$. art. 33

${ }^{226}$ Canada, Patent Protection of Pharmaceuticals, supra note 213, § IV(B)(1); TRIPS Agreement, supra note 6 , art. 30 .

227 TRIPS Agreement, supra note 6, art. 30.

${ }^{228}$ Canada, Patent Protection of Pharmaceuticals, supra note 213, § IV(B)(1)(a)(ii),. § IV(B)(1).

${ }^{229} \mathrm{Id}$.

${ }^{230}$ Id. § VIII. 
primarily focusing on the economic interests of the right holder, ${ }^{231}$ while giving little consideration to the Canadian arguments about pressing public interests. ${ }^{232}$ Although the Panel acknowledged Articles 7 and 8 (the objectives and principles of the TRIPS Agreement), it analyzed the limited exceptions available under Article 30 of TRIPS without reference to these flexibility provisions. ${ }^{233}$ As a result, the Panel prioritized the interests of the patent owner over the goal of promoting public health without any apparent consideration of these guiding principles. ${ }^{234}$

Hence, the Canadian government was required to justify its public health policy as an exception to the patent right. This approach makes it difficult to promote human development because it renders human development an exception rather than the norm. Protecting intellectual property rights, and the market gains associated with intellectual property protection, has become the standard. Yet, there was no need for the E.U. to justify the patent protection in light of Canada's health policies. Since advancing public health was not seen as a part of the objectives of patent law, it was not a factor in the Panel's determination, and the domestic policy considerations were rendered irrelevant.

In the domestic context, courts often consider policy objectives when determining the appropriate balance of rights. In Kimble v. Marvel, for example, the United States Supreme Court reaffirmed that after the patent expires, so does the right of the patentee to claim exclusivity over the patented product. ${ }^{235}$ Among other things, the Court was guided by the patent policy goal of making the invention freely available to the public after the patent term expires. ${ }^{236}$ This policy objective took precedence over the settlement agreement in which Marvel agreed to pay Kimble for a certain period of time.

Although the cases are different in many ways, in both Kimble and the WTO case, the courts were asked to consider the relationship between the rights of the patentees and the interests of the public in having access to the patented product immediately after the patent expired. In Kimble, a case about technology relating to a toy, the Court prioritized public access as a patent policy objective. By comparison, in Canada Pharmaceuticals, a case about access to medicines in Canada, the Panel concluded it was not acceptable for a drug to be produced during the patent term, even if it was only made available to the public after the patent term expired. The WTO Panel did not engage in a similar policy balancing as between the stated

${ }^{231} I d$. § VII(E)(1)(c); see J. Janewa OseiTutu, Value Divergence in Global Intellectual Property Law, 87 IND. L.J. 1639, 1676-77 (2012).

${ }^{232}$ See OseiTutu, supra note 231, at 1677-78.

${ }^{233}$ Canada, Patent Protection of Pharmaceuticals, supra note 213, § VII(E)(1)(c). Rather, the Panel seems to have accepted the E.U.'s argument that the balancing goals of TRIPS had already been taken into consideration in negotiating the final text of the agreement. See id.

${ }^{234}$ See id. The Panel evaluated the curtailment of the patent right, given that third parties could make and use the patented invention before the expiry of the patent term. Id.

${ }^{235}$ Kimble v. Marvel Entm't, LLC, 135 S. Ct. 2401, 2413 (2015). In Marvel, a case about technology relating to a Spiderman toy, the court prioritized public access as a patent policy objective. See id.

${ }^{236} I d$. at 2413 ("[T] he Court [has] held ... that the day after a patent lapses, the formerly protected invention must be available to all for free."). 
Canadian government concern about access to medicines vis-à-vis the rights of the company to exploit its market advantage throughout the full patent term, and even after the patent had expired.

In the international context, one might query whose policy the WTO should take into consideration when deciding a dispute between two or more nations that have committed to the trade obligations in the agreement. Arguably, the policy goals of one nation should not take priority over the policy goals of another. This is why it is important to acknowledge human development as an objective of global intellectual property, instead of as a domestic policy consideration that can be discounted. When nations structure their intellectual property laws to promote human development goals, such as public health, this should be understood as a policy goal that is one of the objectives of trade-related intellectual property. ${ }^{237}$

If human development is an objective of trade-based intellectual property law, then making a generic drug available to the public as soon as the patent expires may further the goals of the international intellectual property regime. The law might still have required some modifications to limit the amount of drug that could be manufactured, for example. However, the significant difference would be that a law designed to support health would not need to be defended as an exception to the rule that intellectual property must be protected. Rather, promoting health would be interpreted as one of the goals of trade-based intellectual property, and the challenged laws could be assessed through that lens.

Human development should be recognized as the norm in intellectual property law because the intellectual property objectives of stimulating innovation and progress are for the purpose of improving the human condition. Creating economic wealth is an important part of this, but it is equally important to promote health, education and human flourishing. A healthy, literate population is also a more productive population. ${ }^{238}$ To be clear, promoting human development does not mean that intellectual property rights should not be respected. Prioritizing human development may require greater intellectual property protection in some instances, but less intellectual property protection in other instances.

Next, I will discuss another dispute that raised issues about the relationship between intellectual property protection and access to medicines.

\section{B. Indian Generics Goes Beyond "Flexibilities"}

The dispute between India and the E.U. about the seizure of generic drugs in transit raised access concerns, but the parties resolved the matter without

${ }^{237}$ See generally Doha Declaration on Health, supra note 183.

${ }^{238}$ Nicole Huberfeld, Federalizing Medicaid, 14 U. PA. J. CONST. L. 431, 437 (2011) ("The social insurance movement was not just about solidarity, it also furthered the economic realities that a healthier population is a more productive population ...."). 
Io5

adjudication. ${ }^{239}$ However, India made some creative and effective arguments that enabled India to prevail in the conflict.

When the Government of the Netherlands seized a number of shipments of generic drugs as the shipments transited through the Netherlands on their way to other countries, the Indian government initiated a complaint process through the WTO. ${ }^{240}$ The Brazilian government, as the recipient of some of the generic drugs that were seized, also initiated a WTO complaint. ${ }^{241}$ The generic drugs coming from India were seized while transiting through the Netherlands on their way to Brazil. ${ }^{242}$ This was due to an E.U. law that allowed the authorities to seize goods that were suspected of infringing an intellectual property right. ${ }^{243}$ The drug was neither patented in India nor in the destination countries. ${ }^{24}$ However, under Dutch law, drugs manufactured in India were treated as though they had been made in the Netherlands. ${ }^{245}$

As part of India's complaint filed with the WTO, India referred to the Doha Declaration on Health and to human rights instruments to argue that intellectual property rights should not interfere with the right to health. ${ }^{246}$ In particular, India argued that the TRIPS obligations should be interpreted in light of the Doha

${ }^{239}$ This did not lead to the establishment of a dispute settlement panel but ended with the request for consultations. Request for Consultations by India, European Union and a Member State-Seizure of Generic Drugs in Transit, WTO Doc. WT/DS408/1 (May 19, 2010) [hereinafter Request for Consultations by India]; see also Brook K. Baker, Settlement of India/EU WTO Dispute re Seizures of In-Transit Medicines: Why the Proposed EU Border Regulation Isn't Good Enough, AM. U. WASH. C.L., DigitAL COMMONS 1 (Jan. 1, 2012), digitalcommons.wcl.american.edu/cgi/viewcontent.cgi?article=1026\&context=research.

${ }^{240}$ Request for Consultations by India, supra note 248, at 1 ("Based on complaints of alleged infringement by alleged owners of patents over the last two years, customs authorities in the Netherlands have seized a substantial number of consignments of generic drugs from India in transit through the Netherlands. India understands that these seizures were made by applying the so-called 'manufacturing fiction' under which generic drugs actually manufactured in India and in transit to third countries were treated as if they had been manufactured in the Netherlands. These consignments were initially detained and later, either destroyed or returned to India. In a few cases, the consignments were permitted to proceed to the destination country after considerable delay. Available evidence confirms that the customs authorities seized at least 19 consignments of generic drugs in 2008 and 2009 while in transit through the Netherlands, 16 of which originated in India.").

${ }^{241}$ Request for Consultations by Brazil, European Union and a Member State-Seizure of Generic Drugs in Transit, WTO Doc. WT/DS409/1 (May 19, 2010).

${ }^{242}$ Request for Consultations by India, supra note 248, at 1.

${ }^{243}$ Mônica Steffen Guise Rosina \& Lea Shaver, Why are Generic Drugs Being Held up In Transit? Intellectual Property Rights, International Trade, and the Right to Health in Brazil and Beyond, 40 J.L. MED. \& ETHICS 197, 200 (2012).

${ }^{244}$ Patent rights are territorial in nature. This means that there is no such thing as a global patent. Rather, patent protection must be sought in each country. Protecting Intellectual Property Rights (IPR) Overseas, U.S. PAT. \& TRADEMARK OFF., http:// http://www.uspto.gov/patents-gettingstarted/international-protection/protecting-intellectual-property-rights-ipr (last visited Oct 23, 2016).

${ }^{245}$ Request for Consultations by India, supra note 248, at 1 .

${ }^{246} I d$. at 3 . 
Declaration on Health and the International Covenant on Economic Social and Cultural Rights. ${ }^{247}$

One of the TRIPS Agreement exceptions that India raised was Article 30, which, as discussed above, allows limited exceptions to patent protection, so long as these exceptions do not unreasonably interfere with the rights of the patent owner, and take into consideration the interests of third parties. ${ }^{248}$ This is the same provision that was at issue in the Canada Pharmaceuticals case, which Canada lost. ${ }^{249}$

Rather than solely attempting to fit within the exceptions, the Indian government emphasized that the E.U. law was an inappropriate extension of the patent right. ${ }^{250}$ India did not limit its arguments to justifying exceptions to the patent right, even though the Request for Consultations referred to the TRIPS exceptions found in Articles 30 and 31 of the Agreement. ${ }^{251}$ Rather, India argued that the TRIPS obligations must be interpreted in light of the objectives and principles found in Articles 7 and 8 of TRIPS, the Doha Declaration on Health, and the right to health enumerated in Article 12 of the ICESCR. ${ }^{252}$ This type of analysis was a step in the right direction, and it seems to have been an effective strategy. The parties settled the dispute, and the Dutch discontinued their practice of seizing such medications. ${ }^{253}$ India did not pursue further action against the E.U. and the Netherlands.

The aforementioned seizure of generic drugs in transit was the first WTO dispute after the Doha Declaration that raised issues of competing health and intellectual property interests. Since a panel was not established, there was no adjudication, so it is difficult to know with certainty whether the Doha Declaration made a difference. ${ }^{254}$ That said, one cannot discount the ministerial declarations made in Doha as having had no impact on the outcome.

${ }^{247} I d$. ("India considers further that the measures at issue also have a serious adverse impact on the ability of developing and least-developed country members of the World Trade Organization to protect public health and to provide access to medicines for all. Accordingly, the provisions of the TRIPS Agreement referred to above must be interpreted and implemented in light of the objectives and principles set forth in Articles 7 and 8 of the TRIPS Agreement, the Doha Ministerial Declaration on the TRIPS Agreement and Public Health adopted on 14 November 2001 and in the light of Article 12(1) of the International Covenant on Economic, Social and Cultural Rights, which recognizes the right of all persons to the enjoyment of the highest attainable standard of physical and mental health.").

${ }^{248}$ TRIPS Agreement, supra note 6, art. 30.

${ }^{249}$ See Canada Patent Pharmaceuticals, supra note 19.

${ }^{250}$ Request for Consultations by India, supra note 248 at 3.

${ }^{251} \mathrm{Id}$.

${ }^{252} \mathrm{Id}$.

${ }^{253}$ Brook K. Baker, Settlement of India/EU WTO Dispute re Seizures of In-Transit Medicines: Why the Proposed EU Border Regulation Isn't Good Enough, AM. U. WASH. C.L., DigiTAL $\begin{array}{llll}\text { COMMONS } & 1 & \text { (Jan. 2012), }\end{array}$ digitalcommons.wcl.american.edu/cgi/viewcontent.cgi?article=1026\&context=research.

${ }^{254}$ Dispute Settlement: Dispute DS408, WORLD TRADE ORG., https://www.wto.org/english/tratop_e/dispu_e/cases_e/ds408_e.htm (last updated June 22, 2010). 
The dispute between Australia and the E.U. with respect to Australia's Plain Packaging regulations for cigarettes presents a new opportunity to interpret the relationship between intellectual property rights and public health post-Doha.

\section{Australia Prioritizes Health}

Australia's Plain Packaging Legislation was designed to protect the public health. ${ }^{255}$ It has led to a decline in smoking in Australia, ${ }^{256}$ and other countries are planning to adopt, or have already adopted, similar laws. ${ }^{257}$ However, this has been a costly exercise for Australia because of the litigation by Philip Morris and other tobacco companies that are concerned about their trademarks. ${ }^{258}$ Cigarette companies have litigated using provisions in bilateral investment treaties, arguing that barriers to the use of their trademarks amount to expropriation of their property. ${ }^{259}$ Aside from challenges under investment treaties, some WTO members

255 Competition and Consumer (Tobacco) Information Standard 2011, supra note 10, § 1.4 (explaining that the purpose of the legislation is to protect public health); see also Health Warnings, AUSTL. DEP'T OF HEALTH, http://www.health.gov.au/internet/main/publishing.nsf/content/tobaccowarn (last updated June 14, 2016) ("Health warnings are required on all tobacco product packaging for retail in Australia. The graphic health warnings provide a strong and confronting message to smokers about the harmful health consequences of tobacco products and convey the 'quit' message every time a person reaches for a cigarette. The graphics, in combination with the warning statements and explanatory messages, are intended to increase consumer knowledge of health effects relating to smoking, to encourage cessation and to discourage uptake or relapse.").

${ }^{256}$ Shalailah Medhora, Plain Packaging to Thank for Australia's Decline in Smoking, Says Labor, GUARDIAN (Mar. 11, 2015, 11:03 PM), http://www.theguardian.com/society/2015/mar/12/plainpackaging-to-thank-for-australias-decline-in-smoking-says-labor ("Australians are ditching cigarettes at record levels, with the latest quarterly figures from the Australian Bureau of Statistics (ABS) showing a fall of nearly $3 \%$ in tobacco consumption. The seasonally-adjusted figures for the December quarter show a $2.9 \%$ fall in consumption, contributing to a $12.2 \%$ yearly fall from December 2013 to December 2014.").

257 See, e.g., Frances Perraudin, MPs Pass Legislation to Introduce Standardised Cigarette
Packaging,
GUARDIAN
(Mar.
11,
2015,
$1: 37$
$\mathrm{PM})$,

http://www.theguardian.com/politics/2015/mar/11/mps-pass-legislation-introduce-standardised-

cigarette-packaging (reporting that England has voted in cigarette packing legislation similar to that of Australia); Henry McDonald, Ireland Passes Plain Packaging Bill for Cigarettes, GUARDIAN, (Mar. 3, 2015, 2:56 PM), https://www.theguardian.com/world/2015/mar/03/ireland-passes-plain-packagingbill-cigarettes-smoking-tobacco (reporting that Ireland has voted in standardized cigarette packaging legislation).

${ }^{258}$ Peter Martin, Australia Faces $\$ 50 \mathrm{~m}$ Legal Bill in Cigarette Plain Packaging Fight with Philip Morris, SYDNEY MORNING HERALD (July 28, 2015), http://www.smh.com.au/federal-politics/politicalnews/australia-faces-50m-legal-bill-in-cigarette-plain-packaging-fight-with-philip-morris-20150728gim4xo.html ("Australia's legal bill for defending its cigarette plain packaging legislation is set to hit $\$ 50$ million as it battles to contain a case brought by tobacco giant Philip Morris before a tribunal in Singapore. And that is just for the first stage. If in September the three-person extraterritorial tribunal decides Australia has a case to answer, the hearing will move on to substantive matters and the bills will become far bigger.").

${ }^{259}$ Sabrina Tavernise, Tobacco Firms' Strategy Limits Poorer Nations' Smoking Laws, N.Y. TIMES (Dec. 13, 2013), http://www.nytimes.com/2013/12/13/health/tobacco-industry-tactics-limit-poorernations-smoking-laws.html; see generally Cynthia M. Ho, Sovereignty Under Siege: Corporate 
have also challenged the Australian Plain Packaging Legislation as a violation of the TRIPS Agreement. ${ }^{260}$

The Australian Tobacco Plain Packaging Act 2011 prohibits the use of trademarks on retail cigarette packaging except as specifically set out in the law. ${ }^{261} \mathrm{In}$ addition to the limitations on the use of trademarks, the Competition and Consumer (Tobacco) Information Standard 2011 requires that health warnings cover the majority of the packaging for vertical and horizontal cigarette packaging. ${ }^{262}$ Ukraine, Honduras, Indonesia, Cuba, the Dominican Republic all contend that the Australian law is inconsistent with its WTO obligations, including the TRIPS Agreement. ${ }^{263}$

As discussed above, Article 8 of TRIPS allows countries to take measures to promote the public health, provided that such measures are consistent with the Agreement. ${ }^{264}$ But what does it mean to be "consistent with the Agreement?" This dispute presents an opportunity for the WTO to interpret the TRIPS Agreement obligations in light of the Doha Declaration on Health, which was concluded after the Canada Pharmaceuticals case was decided. The Plain Packaging Legislation case is the first WTO case to raise public health issues since that time. The Doha Declaration on Health underscores the importance of interpreting the TRIPS obligations in light of its objectives and principles, which means that a WTO

Challenges to Domestic Intellectual Property Decisions, 30 BERKELEY TeCH. L.J. 213 passim (2015) (explaining why and how large companies are using international treaties as a litigation tool).

${ }^{260}$ Request for Consultations by Ukraine, Australia - Certain Measures Concerning Trademarks and Other Plain Packaging Requirements Applicable to Tobacco Products and Packaging, WTO Doc. WT/DS434/1 (Mar. 13, 2012) [hereinafter Request for Consultations by Ukraine]; Request for Consultations by Dominican Republic, Australia-Certain Measures Concerning Trademarks, Geographical Indications, and Other Plain Packaging Requirements Applicable to Tobacco Products and Packaging, WTO Doc. WT/DS441/1 (July 18, 2012) [hereinafter Request for Consultations by Dominican Republic]; Request for Consultations by Honduras, Australia-Certain Measures Concerning Trademarks and Other Plain Packaging Requirements Applicable to Tobacco Products and Packaging; WTO Doc. WT/DS435/1 (Apr., 4 2012) [hereinafter Request for Consultations by Honduras]; Request for Consultations by Cuba, Australia - Certain Measures Concerning Trademarks, Geographical Indications and Other Plain Packaging Requirements Applicable to Tobacco Products and Packaging, WTO Doc. WT/DS458/1 (May 3, 2013) [hereinafter Request for Consultations by Cuba]; Request for Consultations by Indonesia, Australia-Certain Measures Concerning Trademarks, Geographical Indications and Other Plain Packaging Requirements Applicable to Tobacco Products and Packaging, WTO Doc. WT/DS467/1 (Sep. 20, 2013) [hereinafter Request for Consultations by Indonesia].

${ }^{261}$ Tobacco Plain Packaging Act 2011, supra note 8.

${ }^{262}$ According to Sections 9.13 and 9.14 of the Competition and Consumer (Tobacco) Standard, the health warning must cover at least $75 \%$ of the front of the cigarette packaging. Competition and Consumer (Tobacco) Information Standard 2011, supra note 10. Per sections 9.19 and 9.20, the health warnings must cover at least $90 \%$ of the back of the cigarette packaging. Id.

${ }^{263}$ Request for Consultations by Ukraine, supra note 260 (asserting that the Australian law contradicts the WTO agreement); Request for Consultations by Honduras, supra note 260; Request for Consultations by Indonesia, supra note 260; Request for Consultations by Cuba, supra note 260; Request for Consultations by Dominican Republic, supra note 260.

${ }^{264}$ TRIPS Agreement, supra note 6, art. 8. 
Dispute Resolution Panel should give serious weight to Articles 7 and 8 of the TRIPS Agreement. ${ }^{265}$ A panel was established in May 5, 2014 to hear the dispute. ${ }^{266}$

Professors Frankel and Gervais argue that there is a positive right to use a trademark and that this right has been violated by the Australian Plain Packaging Legislation. ${ }^{267}$ The classic position, however, is that there is no positive right to use a trademark. ${ }^{268}$ This distinction is important if Australia defends its law as a justified exception to the use of the trademark. ${ }^{269}$ If there is no positive right to use a trademark, then arguably there is no interference so long as the trademark owner is able to prevent others from using the trademark.

These technical analyses of the right to use a trademark are relevant, but, if the goal is to promote human progress, the question of whether one has a right to use a trademark, or merely a right to prevent others from using a trademark, becomes less significant. The next Section, which builds on the preceding discussions, will elaborate on the centrality of human development as an objective of trade based intellectual property law.

\section{SHIFTING HuMAN DEVELOPMENT FROM THE MARGIN TO THE CENTER OF INNOVATION AND PROGRESS}

Intellectual property laws can be developed, interpreted, and applied in a manner that provides economic incentives and rewards, while also advancing human progress and development. ${ }^{270}$ Intellectual property protection and human development are not mutually exclusive. This means that patent protection, for instance, can and should promote access to medicines, and copyright can and should facilitate access to education. Advancing human health does not need to be viewed as an exception that is tolerated by intellectual property law.

Unlike public welfare or public interest, human development can be identified and measured using existing, globally recognized mechanisms. As a goal, promoting human development can also be distinguished from human rights, although the two

${ }^{265}$ Doha Declaration, supra note 4, 917.

266 See Dispute Settlement: Dispute DS435, WORLD TraDE ORG., https://www.wto.org/english/tratop_e/dispu_e/cases_e/ds435_e.htm (last updated July 7, 2016). The authority for the Ukraine panel lapsed on May 30, 2016. Per Article 12.12 of Understanding on Rules and Procedures Governing the Settlement of Disputes ("DSU"), if a dispute is suspended for more than twelve months, the authority for the panel lapses. Understanding on Rules and Procedures Governing the Settlement of Disputes art. 12.12, Apr. 15 1994, Marrakesh Agreement Establishing the World Trade Organization, Annex 2, 1869 U.N.T.S 401. At the time this Article was written, the rest of the disputes were in process.

${ }^{267}$ See generally Susy Frankel \& Daniel Gervais, Plain Packaging and the Interpretation of the TRIPS Agreement, 46 VAND. J. TRANSNAT’L L. 1149 (2013).

268 See generally Mark Davison, Plain Packaging and the TRIPS Agreement: A Response to Professor Gervais, 23 AUSTL. INTELL. PROP. J. 160, 160-162 (2013) (providing reasoning as to why there is no positive right to use a trademark).

${ }^{269}$ TRIPS Agreement, supra note 6, art. 17 (limited exceptions for trademarks).

${ }^{270}$ SUNDER, supra note 1 , at 3. 
overlap to a great extent. Human rights can clash, and it can be difficult to determine which right should prevail in the event of a conflict. In addition, some human rights have been extended to corporations. ${ }^{271}$ Human development includes health, education and literacy, as well as economic prosperity and it does not extend to corporate entities. The HDI and the United Nations Millennium Development Goals can help inform this discussion.

\section{A. The United Nations Sustainable Development Goals}

With the beginning of the new millennium in the year 2000, the world's nations came together to eradicate global poverty. In so doing, these nations established eight Millennium Development Goals ("MDGs") with a fifteen-year plan for global development. ${ }^{272}$ The worlds' nations committed to eradicate poverty, and also committed to efforts to improve health and education, and to develop a global partnership for development. ${ }^{273}$ In September 2015, nations from around the world gathered to agree upon post-2015 development goals. ${ }^{274}$ The proposed Sustainable Development Goals build on the MDGs of improvements to health and education, the eradication of poverty, and gender and income inequality. ${ }^{275}$

Sustainable Development Goal ("SDG") 9, for instance, aims to "[b]uild resilient infrastructure, promote sustainable industrialization and foster innovation." ${ }^{276}$ There are eight targets for SDG 9. ${ }^{277}$ Three of these targets appear to be directly related to intellectual property rights. ${ }^{278}$ These include the target of enhancing scientific research, promoting infrastructure development through technological and technical support, and supporting domestic technology development, research, and innovation. ${ }^{279}$

${ }^{271}$ See, e.g., Anheuser-Busch Inc. v Portugal (73049/01), [2007] E.T.M.R. 24 (recognizing a corporation's right to property under the European Convention on Human Rights).

272 United Nations, Millennium Development Goals Report 2015, at 4 (2015).

${ }^{273} I d$. at $4-7$.

${ }^{274}$ Historic New Sustainable Development Agenda Unanimously Adopted by 193 UN Members, U.N., SUSTAINABLE DEV. GOALS (Sept. 25, 2015), http://www.un.org/sustainabledevelopment/blog/2015/09/historic-new-sustainable-developmentagenda-unanimously-adopted-by-193-un-members/. One hundred and ninety-three United Nations members came together to agree on these goals. Id. These Sustainable Development Goals were unanimously adopted by the UN member states. Id.

275 Sustainable Dev. Goals (SDGs), U.N. Dev. Programme, $\mathrm{http} / /$ www.undp.org/content/undp/en/home/sdgoverview/post-2015-development-agenda.html (last visited Oct. 23, 2016).

${ }^{276}$ Goal 9: Build resilient infrastructure, promote sustainable industrialization and foster innovation, U.N. DEV. PROGRAMME, http://www.un.org/sustainabledevelopment/infrastructure-industrialization/ (last visited Oct. 27, 2016).

${ }^{277} I d$.

${ }^{278} I d$.

${ }^{279} \mathrm{Id}$. 


\section{B. The Human Development Index ("HDI")}

Development, innovation and progress can be interpreted strictly in terms of economic benefit to particular individuals or business entities. Arguably, this is consistent with the focus in reward theory because it is concerned with the rewards to the individual. But individual rewards and economic indicators represent only a part of the progress that copyrights and patents help to stimulate. As discussed above, a utilitarian approach to intellectual property does not need to be limited to economic progress.

A tool like the HDI can help to give a more holistic indication of whether progress is occurring. This is because the HDI values economic indicators as well as non-economic indicators in assessing how a society is developing. ${ }^{280}$ The HDI is widely accepted and has been in use for over twenty-five years. ${ }^{281}$ According to the United Nations, "[t]he HDI was created to emphasize that people and their capabilities should be the ultimate criteria for assessing the development of a country, not economic growth alone." 282 This index is based on life expectancy, levels of education, and gross national income. ${ }^{283}$ So, it gives us some indication of how well individuals are doing in a given society. The HDI can also be used to evaluate national policy choices, "asking how two countries with the same level of [gross national income] per capita can end up with different human development outcomes." 284

The HDI is an imperfect tool, but it is a shift in the right direction. ${ }^{285}$ Furthermore, the current methods of evaluating intellectual property laws present their own challenges. The difficulty in accurately assessing the financial harm caused by global intellectual property infringement, for instance, has not prevented industry associations and governments from using financial harm as a basis for insisting on higher intellectual property standards. ${ }^{286}$ Furthermore, the lack of consistent empirical evidence to justify patent and copyright laws has not led to reduced intellectual property protections. ${ }^{287}$

The centrality of human development is pertinent to developing and developed countries alike. As the discussion about the disputes involving Canada and Australia

${ }^{280}$ U.N. Dev. Programme, Human DEvELOPMENT REPORTS (2014) [hereinafter HuMAN DEVELOPMENT REPORTS].

28125 Years of Human Development Indices, InT'L TrAdE Union CONFEDERATION (Apr. 9, 2015), http://www.ituc-csi.org/25-years-of-human-development?lang=en.

${ }^{282}$ HUMAN DEVELOPMENT REPORTS, supra note 280.

${ }^{283} \mathrm{Id}$.

${ }^{284} I d$.

285 See Paul Streeten, Human Development: Means and Ends, 84 AM. ECON. Ass'N. 232, 235-36 (1994) (discussing the strengths and weaknesses of the HDI).

${ }^{286}$ THE COMM'N ON THE THEFT OF AM. INTELLECTUAL PROP., THE IP COMMISSION REPORT 2-3 (2013)

${ }^{287}$ See Lemley, supra note 102, at 1334-35. 
clearly illustrates, human development goals, such as those relating to public health, are important for all nations. However, human development is critical for many developing countries because they lag behind in terms of health, education, and economic well-being. The next Section will briefly consider some developing country national and regional approaches.

\section{An African Example}

The African Union (“A.U.") was established in 2001 to create an "integrated, prosperous, and peaceful Africa ...." ${ }^{288}$ It is comprised of 54 member states, which represents all the countries on the continent. ${ }^{289}$ The A.U. has developed a Science, Technology and Innovation Strategy for Africa. ${ }^{290}$ The A.U. Science, Technology and Innovation Strategy has innovation and human development as its main goals. ${ }^{291}$ In particular, the A.U. underscores the importance of achieving sustainable socioeconomic growth, reducing poverty, achieving food security, promoting public health, and protecting the environment. ${ }^{292}$ This is a model that envisions innovation and human development occurring together. Presumably, African countries that accept this model will develop and implement intellectual property laws that promote human development as an integral part of the innovation model.

A group of developing countries, called the Group of Fifteen, Summit Level Group of Developing Countries, has prepared a paper titled Intellectual Property for Development. ${ }^{293}$ The Group of Fifteen ("G-15") also recognizes that intellectual property should play a role in human development. ${ }^{294}$ The G-15, which includes countries from a number of continents, aims to involve itself in international negotiations, with a view to making the intellectual property system more inclusive. ${ }^{295}$

${ }^{288} A U$ in a Nutshell, AFr. UNION, http://www.au.int/en/about/nutshell (last visited Oct. 23, 2016).

${ }^{289}$ Member States of the $A U$, AFR. UNION, http://www.au.int/en/AU_Member_States (last visited Oct. 23, 2016).

290 African Union Commission, Science, Technology and Innovation Strategy for Africa 2024, http://hrst.au.int/en/sites/default/files/STISA-Published\%20Book.pdf.

${ }^{291} I d$. at 10.

${ }^{292} I d$.

${ }^{293}$ IP for Development, GROUP OF FIFTEEN, (2014), http://g15.org/g-15-joint-statements/ip-fordevelopment/. The member countries are Algeria, Argentina, Brazil, Chile, Egypt, India, Indonesia, Islamic Republic of Iran, Jamaica, Kenya, Malaysia, Mexico, Nigeria, Senegal, Sri Lanka, Bolivarian Republic of Venezuela, and Zimbabwe. Id.

${ }^{294}$ Group of Fifteen, Working Group on Sectoral Cooperation Concept Note on Intellectual Property, 1, http://g15.org/wp-content/uploads/2014/04/G15-WGSC-Thematic-area-IP.pdf ("An important angle in recent debates has been the broad implications for development, as a public policy, and the role of developing countries in the evolution of the international system. Indeed, Developing Countries are calling for a balanced international intellectual Property system that takes into account the interest of the IP right's holders as well as the public interest of the larger society.").

${ }^{295} \mathrm{Id}$. at 2. 
In fact, the majority of WTO member states are developing countries. ${ }^{296}$ As these nations implement their TRIPS obligations, they should do so in a manner that is consistent with their own views on innovation, progress, and development. National and regional approaches to intellectual property obligations can influence the interpretation of international obligations. For example, Article 31 of the VCLT ${ }^{297}$ guides treaty interpretation at international law. Since subsequent practice is relevant in interpreting international obligations, ${ }^{298}$ policies should be implemented with an understanding that promoting human development is consistent with the objectives of trade-related intellectual property law.

On a national level, Ghana, for example, has been working with the Swiss government to revise Ghanaian intellectual property laws. ${ }^{299}$ This may mean that Ghana will be inclined to develop Western-oriented policies and those promoted by organizations such as WIPO and the WTO. However, the country would be well advised to continue to prioritize its own development goals. For instance, the Ghanaian Constitution of 1992 recognizes the right to education and the right to cultural practices, provided such practices do not dehumanize any person. ${ }^{300}$ The Ghanaian Copyright Act recognizes a right to folklore, which vests in the President in trust for the people of Ghana. ${ }^{301}$ The folklore is protected indefinitely. ${ }^{302}$

Implementing domestic protections for traditional knowledge, traditional cultural expressions, and folklore within national intellectual property laws signals commitment to protecting and promoting traditional cultures within the context of an intellectual property regime. It would also be helpful to include language within the intellectual property laws that signals that human progress is an explicit objective of national intellectual property policy.

\section{CONCLUSION}

As this Article has argued, intellectual property rules that have been subsumed within a trade framework should be interpreted not only in light of the purposes of intellectual property law, but also in light of the purposes of trade law. This means that human development should not be merely taken into consideration in

296 Who Are the Developing Countries in the WTO?, WORLD TrADE ORG., https://www.wto.org/english/tratop_e/devel_e/d1who_e.htm (last visited Oct. 24, 2016).

${ }^{297}$ VCLT, supra note 127 , art. 31.

${ }^{298} I d$.

299 Ghana's Intellectual Property Rights Launched, GOV'T OF GHANA, http://www.ghana.gov.gh/index.php/media-center/news/2357-ghana-s-intellectual-property-rights-

launched (last visited Oct. 24, 2016); see also Abena Ntrakwah-Mensah, Ghana Launches a National Intellectual Property Policy, LEXOLOGY, (Jan. 25, 2016), http://www.lexology.com/library/detail.aspx?g=89862cf5-4fb1-4d5e-88b6-34112cbc9fb4 (explaining in greater detail the changes Ghana is making to its IP policy).

${ }^{300}$ The Constitution of the Republic of Ghana, May 8, 1992, arts. 25, 26.

301 The Copyright Act 2005, § 4 (Ghana).

${ }^{302}$ Id. § 17. 
international intellectual property disputes. Instead, trade-related intellectual property must promote peace, prosperity, and sustainable development. There are strong textual and theoretical justifications for concluding that global intellectual property should promote innovation and progress that advances human development.

Human development is valuable in and of itself, ${ }^{303}$ but it also leads to increased productivity. ${ }^{304}$ Thus, trade-based intellectual property laws that further human development will promote progress in a variety of areas, not as an exception, but as the norm. This could result in stronger intellectual property protections in some instances, and weaker intellectual property protections in others, depending on whether the law in question is advancing human progress. ${ }^{305}$ The goal is to create greater space for laws and policies that promote health, education, and economic development. Global intellectual property standards, and the corresponding national intellectual property laws can, and should, be structured and interpreted to facilitate laws and policies that promote human development.

This approach is both feasible and practical. Although human development may seem somewhat nebulous and difficult to measure, there are tools, such as the United Nations HDI, for assessing human development, just as there are tools for evaluating economic prosperity. Indeed, economic development is only one indicium of human development. The HDI factors, however, recognize that economic development alone is not a sufficient indicium of human progress. The innovation and progress that intellectual property seeks to stimulate is, ultimately, for the purpose of improving the human condition. It should be clear, therefore, that innovation and human development are not mutually exclusive. To the contrary, intellectual property can play an essential role in promoting human development.

${ }^{303}$ Streeten, supra note 285, at 232 ("Human development puts people back at center stage . . . .).

${ }^{304} I d$., at 232 ("There are six reasons why we should promote human development and poverty eradication. First, and above all, it is an end itself, that needs no further justification. Second, it is a means to higher productivity. A well-nourished, healthy, educated, skilled, alert labor force is the most important productive asset. This has been widely recognized, though it is odd that Hondas, beer, and television sets are often accepted without questioning as final consumption goods, while nutrition, education, and health services have to be justified on grounds of productivity."). health.

305 This includes technological progress, economic prosperity, and improved access to education and 